\title{
Generation of High Quality Biogenic Silica by Combustion of Rice Husk and Rice Straw Combined with Pre- and Post-Treatment Strategies-A Review
}

\author{
Hossein Beidaghy Dizaji ${ }^{1,2, *}$, Thomas Zeng ${ }^{1}$, Ingo Hartmann ${ }^{1}$, Dirk Enke ${ }^{2}$, \\ Thomas Schliermann ${ }^{1}$, Volker Lenz ${ }^{1}$ and Mehdi Bidabadi ${ }^{3}$ \\ 1 DBFZ Deutsches Biomasseforschungszentrum gemeinnützige GmbH, 04347 Leipzig, Germany; \\ Thomas.Zeng@dbfz.de (T.Z.); Ingo.Hartmann@dbfz.de (I.H.); Thomas.Schliermann@dbfz.de (T.S.); \\ Volker.Lenz@dbfz.de (V.L.) \\ 2 Institute of Chemical Technology, Leipzig University, 04103 Leipzig, Germany; dirk.enke@uni-leipzig.de \\ 3 School of Mechanical Engineering, Department of Energy Conversion, Iran University of Science and \\ Technology (IUST), Narmak, 16846-13114 Tehran, Iran; bidabadi@iust.ac.ir \\ * Correspondence: hossein.beidaghy@dbfz.de
}

Received: 29 January 2019; Accepted: 7 March 2019; Published: 14 March 2019

\begin{abstract}
Utilization of biomass either as a renewable energy source or for the generation of biogenic materials has received considerable interest during the past years. In the case of rice husk (RH) and rice straw (RS) with high silica contents in the fuel ash, these approaches can be combined to produce high-grade biogenic silica with purities $>98 \mathrm{wt} \%$ from combustion residues. The overall process can be considered nearly neutral in terms of $\mathrm{CO}_{2}$ emission and global warming, but it can also address disposal challenges of rice husk and rice straw. For the resulting biogenic silica, several advanced application opportunities exist, e.g., as adsorbents, catalysts, drug delivery systems, etc. This article provides a comprehensive literature review on rice husk and rice straw combustion as well as applied strategies for raw material pre-treatment and/or post-treatment of resulting ashes to obtain high quality biogenic silica. Purity of up to $97.2 \mathrm{wt} \% \mathrm{SiO}_{2}$ can be reached by combustion of untreated material. With appropriate fuel pre-treatment and ash post-treatment, biogenic silica with purity up to $99.7 \mathrm{wt} \%$ can be achieved. Studies were performed almost exclusively at a laboratory scale.
\end{abstract}

Keywords: biogenic silica; rice husk; rice straw; ash quality; combustion

\section{Introduction}

According to the report of International Energy Agency (IEA) in 2017, the worldwide share of renewable energy reached $23.9 \%$ in the electricity sector, $10.3 \%$ for power production and $3.4 \%$ for transportation. A further increase to $29.4 \%, 11.8 \%$ and $3.8 \%$, respectively, is expected until 2023 [1]. Besides solar, hydrothermal and wind energy, bioenergy, in particular the exploitation and valorization of agricultural side products and biogenic residues, will play an important role to enable this sustainable development.

Biomass needs to fulfill the following criteria as a sustainable resource of energy: (1) it should be readily available; (2) arable land for food resources should not be affected by biomass for energy generation; and (3) it should produce zero waste and have no negative impact on the environment [2]. In this regard, rice husk (RH) and rice straw (RS) as by-products in rice production and milling processes can fulfill these criteria. Rice represents the second largest share of any crop in the world based on the report of Food and Agriculture Organization of the United Nations (FAO) [3], and the amount is steadily increasing, Figure 1. The world capacity in production of paddy rice in 2015 and 2016 was around 739 and 755 million tons, respectively [4,5]. According to the FAO rice market 
monitor [4], there are more than 50 countries with paddy rice production, with the largest cumulated production originating from Asia (681.8 million tons) followed by America (36.3 million tons) and Africa (32.6 million tons), while Europe and Oceania provide only marginal contributions of 4.1 million tons and 0.3 million tons, respectively.

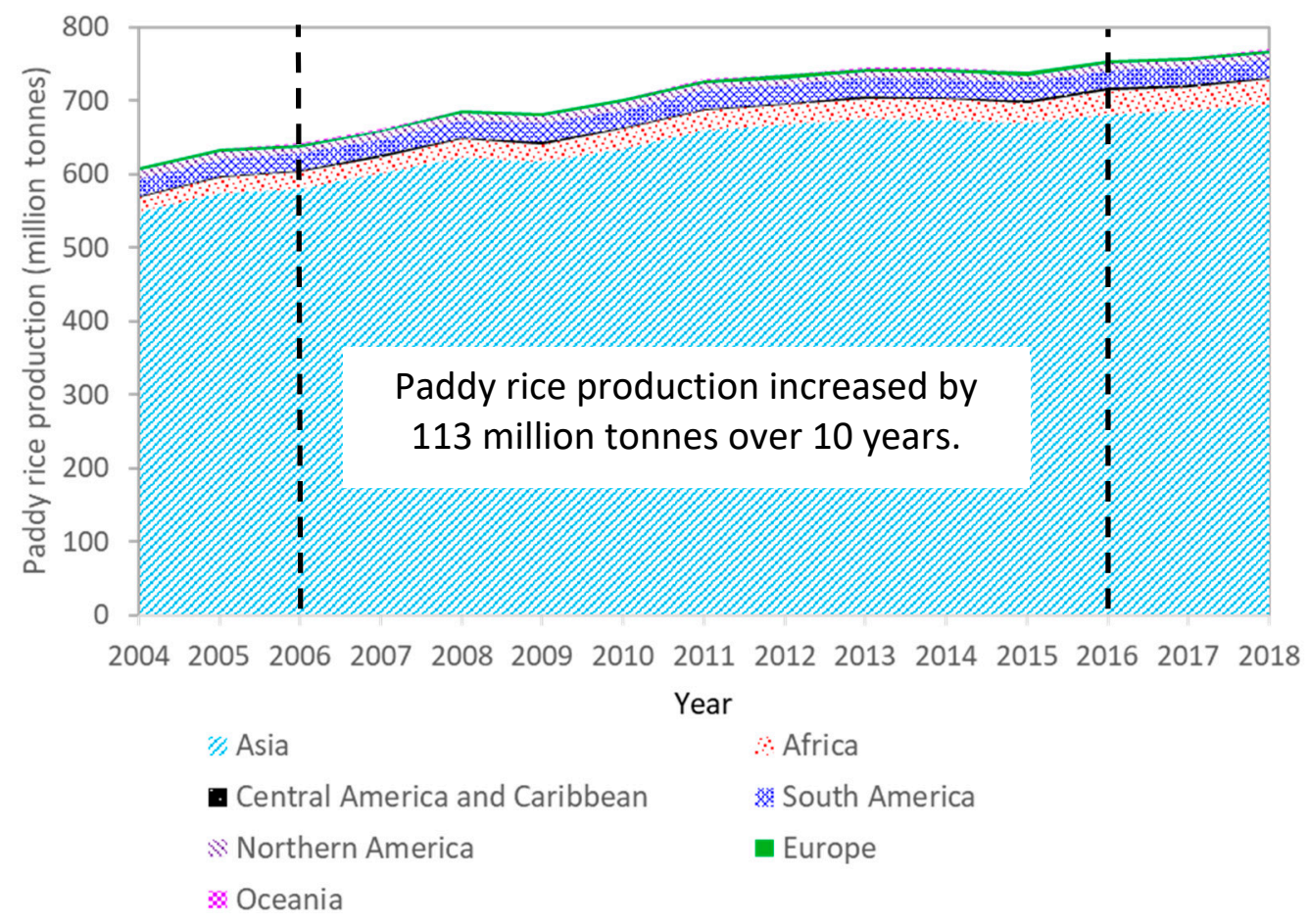

Figure 1. Paddy rice production worldwide (data adapted from reports of FAO between 2006 and 2018 [4-16]); values for 2017 and 2018 are estimated and forecasted data according to the latest report of FAO [4].

Depending on the crop and harvesting method, approximately $20-25$ and $40-60 \mathrm{wt} \% \mathrm{db}$ (dry basis) of paddy rice are RH and RS, respectively $[17,18]$. RH and RS do not compete with food resources for land usage, and because of the abrasive structure and low nutritional value, they are not suitable for food and fodder, and usually are disposed [19-21]. Consisting predominantly of organic matter, i.e., cellulose, hemicellulose, and lignin, $\mathrm{RH}$ and RS are applicable for the use as sustainable fuel for energy generation [22-24]. After combustion of RH and RS, approx. 10-20 wt \% of the initial fuel remains as ash rich in silica (i.e., "biogenic silica"). It can be an economically valuable material for various applications including the cement and concrete industry [25-27], an adsorbent to remove heavy metal ions such as lead (II), mercury (II), zinc (II) and nickel (II) ions from wastewater streams, as catalyst [28-38], for synthesis of zeolites and mesoporous silica [39-46] or for drug delivery systems $[47,48]$. Depending on the anticipated application, biogenic silica is required with different purities. For the utilization as pozzolan in concrete, a silica purity of at least $97 \mathrm{wt} \% \mathrm{db}$ is sufficient [49]. In contrast, advanced applications such as electronics [50] and solar applications [51] require silica purity of up to $99.9 \mathrm{wt} \% \mathrm{db}$. Similarly, different characteristics are desirable depending on the desired application, e.g., negligible slagging tendencies [52], low carbon content and high silica purity for synthesizing advanced materials [53], whiteness and proper particle size for filler applications [54], amorphous structure and an optimized pore system (high specific surface area) [53,55].

Commonly, porous silica is produced on an industrial scale by precipitation from alkaline silicates [50]. Alkaline silicates (water glass) are typically obtained from carbonate powders reacting with silica sand, which is a very energy intensive process and requires very high temperatures (approx. $\left.1400^{\circ} \mathrm{C}\right)[50,56]$. Water glass can also be produced by hydrothermal treatment of sand with lyes, which is also an energy consuming procedure [57]. The traditional process is not only expensive, but also it is 
hazardous to the environment because during the production of 1 ton of silica, approximately 0.23 ton carbon dioxide, 0.74 ton sodium sulfate and 20 tons of waste water are produced, and it violates the principle of sustainable development [50]. Therefore, an economically feasible and environmentally benign route as an alternative method is required to produce silica. In this respect, a combined energy application and biogenic silica production from RH and RS under controlled conversion conditions would be a promising approach regarding climate protection and zero waste production. Currently, open burning and land filling are the common strategies for RH and RS disposal, which have their own challenges including air pollution, greenhouse gas emission, and large landfill space occupancy because of their low density $[24,58]$. Furthermore, uncontrolled open burning of these materials produces crystalline ash with high emissions [59], which is well recognized as a lung carcinogen as well as the health risk from silicosis caused by silica deposition in the lung tissue [60,61]. To overcome these issues, researchers have been investigated feasible, economical, and environmentally friendly strategies to convert RH and RS into pure biogenic silica via combustion based on various scientific publications [53,54,62-73] and patents [74].

Several studies have been carried out to review the field of biogenic silica production and combustion of RH and RS as raw materials [24,50,51,55,75-89]. Most of these studies have focused on applications of the rice husk ash (RHA), rice straw ash (RSA) and pure biogenic silica $[50,75,81,88-90]$ or the synthesis of advanced materials from RHA and RSA $[50,76,77,90]$, influence of RHA and RSA on concrete and cement properties $[78,80,86,87]$ or energy and power generation using RH and RS $[79,82,85]$. However, to the best of our knowledge, there is no review highlighting the combination of pre-treatment strategies as well as post-treatment of the ashes with combustion in order to produce high quality biogenic silica from RH and RS. This review provides a comprehensive literature survey to cover both treatment and combustion for high quality biogenic silica production. First, fuel properties of RH and RS are reviewed and compared with clean wood. Subsequently, combination of several pre-treatment strategies to increase the quality of biogenic silica including chemical pre-treatment and combustion of the raw materials as well as post-treatment of RHA and RSA are discussed.

\section{Fuel Properties of Rice Husk and Rice Straw}

The organic matter of RH and RS consists predominantly of cellulose, hemicellulose, and lignin [91]. Table 1 lists organic contents, proximate and ultimate analysis as well as the ash compositions of RH and RS. Wood is included as a reference material for comparison. Fuel properties of high quality wood pellets fulfilling requirements of class A1 of the ENplus certification scheme were obtained from Pollex et al. [92]. According to Table 1, the ash obtained from wood uncontaminated by soil impurities is mainly composed of alkaline earth metals followed by silicon and potassium [93-97]. According to Table 1, since RH and RS have different ash forming elements than wood, they show completely different ash melting behavior. The ash content of RH and RS is one order of magnitude higher than the ash content of clean wood. Silicon is by far the most abundant element among the inorganic matter both in RH and RS [58,59,72,98-101]. Ca, Mg, K, Na, P, S, Cl, and Al are also included but to a far lesser extent $[59,73,98,99,102-105]$. Association of these ash forming elements as well as their distribution in the biomasses have a major impact on ash melting behavior [106] and consequently determine the remaining silica purity and quality [105,107-109]. 
Table 1. Fuel properties of RH, RS, and wood (data were taken from [23,59,99,102,110-155] for RH, from [105,109,112,119-121,125,135,136,145,156-175] for RS and from [92,110,176-178] for wood; n: number of data sets.

\begin{tabular}{|c|c|c|c|c|c|c|c|c|c|c|c|c|}
\hline Characteristic & \multicolumn{4}{|c|}{ Rice Husk (RH) } & \multicolumn{4}{|c|}{ Rice Straw (RS) } & \multicolumn{4}{|c|}{ Clean Wood Pellet ${ }^{1}(W)$} \\
\hline Organic Type & \multicolumn{4}{|c|}{ CHL and HLC } & \multicolumn{4}{|c|}{ CHL } & \multicolumn{4}{|c|}{ CHL } \\
\hline Inorganic Type & \multicolumn{4}{|c|}{ S Type } & \multicolumn{4}{|c|}{ S Type } & \multicolumn{4}{|c|}{ C Type } \\
\hline \multirow[t]{2}{*}{ Inorganic Sub-Type } & \multicolumn{4}{|c|}{ HA } & \multicolumn{4}{|c|}{ HA } & \multicolumn{4}{|c|}{ LA } \\
\hline & Mean & Minimum & Maximum & $\mathbf{n}$ & Mean & Minimum & Maximum & $\mathbf{n}$ & Mean & Minimum & Maximum & $\mathbf{n}$ \\
\hline Moisture content (MC), wt \% & 8.79 & 4.64 & 12.08 & 21 & 8.74 & 5.58 & 13.06 & 12 & 6.90 & 3.30 & 10.80 & 249 \\
\hline Ash content $(A C)$, wt $\% \mathrm{db}$ & 16.30 & 7.68 & 24.60 & 48 & 16.52 & 9.22 & 22.60 & 26 & 0.40 & 0.22 & 0.68 & 249 \\
\hline Volatile matter (VM), wt \% db & 65.77 & 51.98 & 81.60 & 43 & 67.82 & 49.00 & 80.20 & 18 & 83.75 & 82.00 & 84.90 & 4 \\
\hline Fixed carbon (FC), wt \% db & 15.92 & 12.40 & 25.10 & 41 & 15.18 & 6.62 & 28.40 & 17 & 15.59 & 14.07 & 17.20 & 4 \\
\hline $\mathrm{O}, \mathrm{daf}$ & 38.51 & 29.33 & 53.70 & 48 & 38.01 & 29.23 & 53.64 & 26 & 46.95 & 43.7 & 50.54 & 3 \\
\hline $\mathrm{H}$, daf & 5.31 & 4.30 & 7.50 & 48 & 5.06 & 3.56 & 6.88 & 27 & 6.14 & 6.03 & 6.30 & 3 \\
\hline $\mathrm{N}$, daf & 0.84 & 0.09 & 4.26 & 47 & 0.76 & 0.17 & 1.41 & 27 & 0.11 & 0.05 & 0.51 & 174 \\
\hline S, daf & 0.08 & 0.00 & 0.34 & 5 & 0.20 & 0.06 & 0.66 & 23 & 0.008 & $<0.005$ & 0.037 & 249 \\
\hline $\mathrm{Cl}$, daf & 0.11 & 0.01 & 0.20 & 7 & 0.57 & 0.08 & 1.01 & 11 & 0.009 & $<0.005$ & 0.042 & 249 \\
\hline Low heating value (LHV) (MJ/kg) & 14.14 & 12.30 & 15.70 & 12 & 14.94 & 12.73 & 17.25 & 3 & 17.7 & 16.6 & 19.2 & 220 \\
\hline Cellulose, wt \% & 32.87 & 25.20 & 43.80 & 9 & 37.40 & 37.00 & 37.80 & 2 & 45.20 & 45.20 & 45.20 & 1 \\
\hline Hemicellulose, wt \% & 26.09 & 18.10 & 44.90 & 9 & 24.00 & 22.70 & 25.30 & 2 & 32.70 & 32.70 & 32.70 & 1 \\
\hline Lignin, wt \% & 21.73 & 13.60 & 34.80 & 9 & 18.45 & 13.60 & 23.30 & 2 & 22.10 & 22.10 & 22.10 & 1 \\
\hline $\mathrm{Al}_{2} \mathrm{O}_{3}{ }^{3}$ & 0.34 & 0.17 & 0.78 & 7 & 0.59 & 0.07 & 1.94 & 14 & 3.63 & 4.43 & 2.65 & 81 \\
\hline $\mathrm{Fe}_{2} \mathrm{O}_{3}$ & 0.23 & 0.10 & 0.40 & 8 & 0.46 & 0.10 & 0.98 & 13 & 1.72 & 1.09 & 2.67 & 3 \\
\hline $\mathrm{K}_{2} \mathrm{O}$ & 4.31 & 2.29 & 8.30 & 8 & 13.85 & 11.30 & 20.92 & 14 & 19.84 & $<4.37$ & 10.53 & 249 \\
\hline $\mathrm{MgO}$ & 0.72 & 0.19 & 2.13 & 8 & 2.13 & 1.49 & 5.02 & 13 & 8.24 & 32.53 & 5.00 & 249 \\
\hline $\mathrm{MnO}$ & 0.13 & 0.02 & 0.24 & 2 & 0.28 & 0.27 & 0.29 & 3 & 2.51 & 0.40 & 4.61 & 2 \\
\hline $\mathrm{Na}_{2} \mathrm{O}$ & 0.19 & 0.03 & 0.37 & 7 & 1.31 & 0.14 & 2.71 & 14 & 1.20 & $<1.15$ & 8.64 & 249 \\
\hline $\mathrm{P}_{2} \mathrm{O}_{5}$ & 1.05 & 0.43 & 3.70 & 7 & 1.65 & 0.61 & 2.65 & 12 & 4.68 & 3.76 & 6.39 & 208 \\
\hline $\mathrm{SiO}_{2}$ & 89.92 & 86.92 & 94.38 & 8 & 71.33 & 55.08 & 82.13 & 14 & 23.72 & $<45.61$ & 42.90 & 249 \\
\hline $\mathrm{SO}_{3}$ & 0.68 & 0.34 & 0.96 & 5 & 1.56 & 0.84 & 4.95 & 10 & 3.38 & 0.80 & 5.30 & 3 \\
\hline $\mathrm{TiO}_{2}$ & 0.02 & 0.01 & 0.02 & 5 & 0.03 & 0.01 & 0.09 & 9 & 0.89 & 0.1 & 1.6 & 3 \\
\hline
\end{tabular}

${ }^{1}$ wood uncontaminated by soil impurities. ${ }^{2}$ dry ash-free basis. ${ }^{3}$ reported values are on ash bases 
Origin of the raw materials can have a significant impact on the inorganic composition of fuel ashes of RH and RS. For instance, as shown in Table 2, RH from Egypt, Cambodia, and Italy was evaluated in the same laboratory with the same measurement techniques [72,98]. Results highlight that $\mathrm{Si}, \mathrm{K}$ and $\mathrm{P}$ contents of the fuel ash can vary significantly. Differences in compositions are due to a variety of factors, such as climate, soil types, harvesting season, the amount of fertilizers used during the rice cultivation, geographical and environmental aspects [53,179-181].

Table 2. Accompanying ash constituents of RH (wt \% db) from different locations.

\begin{tabular}{|c|c|c|c|c|c|c|c|c|c|c|c|c|c|}
\hline Location & $\mathrm{SiO}_{2}$ & $\mathrm{Na}_{2} \mathrm{O}$ & $\mathrm{K}_{2} \mathrm{O}$ & $\mathrm{CaO}$ & $\mathrm{MgO}$ & $\mathrm{Al}_{2} \mathrm{O}_{3}$ & $\mathrm{Fe}_{2} \mathrm{O}_{3}$ & $\mathrm{P}_{2} \mathrm{O}_{5}$ & $\mathrm{SO}_{3}$ & $\mathrm{Cl}$ & Others ${ }^{1}$ & Method & Ref. \\
\hline Egypt & 57.90 & N.R. & 14.60 & 2.30 & 3.40 & 1.00 & 1.00 & 13.80 & 3.20 & 2.30 & 0.50 & $\mathrm{XRF}^{2}$ & [98] \\
\hline Cambodia & 80.18 & N.R. & 3.89 & 1.55 & 0.81 & 0.83 & 4.29 & 3.80 & 2.05 & N.R. & 2.60 & $\mathrm{XRF}^{2}$ & [72] \\
\hline Italy & 83.20 & N.R. & 2.73 & 1.60 & 1.00 & 0.33 & 3.57 & 4.12 & 1.52 & N.R. & 1.92 & $\mathrm{XRF}^{2}$ & [72] \\
\hline
\end{tabular}

In Table 1, organic and inorganic types of biomass samples are defined according to Vassilev et al. [110,182-184]. Accordingly, Figure 2 illustrates a possible biomass classification based on the organic and inorganic composition. In Figure $2 \mathrm{a}$, biomasses are arranged according to their relative share of cellulose, hemicellulose and lignin. For the majority of biomasses, cellulose is the predominant macromolecule based on the weight portion [110] followed by hemicellulose and lignin (Cellulose > Hemicellulose > Lignin, i.e., CHL). Marine organisms are usually characterized by hemicellulose as the predominant macromolecule and particularly low contents of lignin (Hemicellulose $>$ Cellulose $>$ Lignin, i.e., HCL). Nut shells and pits are often located in the LCH region based on their high lignin contents. RH and RS are usually located in the CHL region and in some cases also in the HLC region in Figure 2a [111]. Figure 2b shows fuel ashes dominated by components in the silicon, calcium, and potassium corners or between the calcium and potassium corners with $S, C, K$, and CK types, respectively [184]. Moreover, sub-types of HA, MA, LA represent high, medium, and low acid tendencies, respectively [184]. In Figure 2b, wood indicates the mean value of 249 datasets for evaluated wood pellet samples presented by Pollex et al. [92,185]. According to Figure 2b, both RH and RS have very low amounts of $\mathrm{CaO}+\mathrm{MgO}+\mathrm{MnO}$ in their fuel ash compositions compared to wood. On the other hand, the silica-based group of metal oxides $\left(\mathrm{SiO}_{2}+\mathrm{Al}_{2} \mathrm{O}_{3}+\mathrm{Fe}_{3} \mathrm{O}_{4}+\mathrm{Na}_{2} \mathrm{O}+\mathrm{TiO}_{2}\right)$ is higher in both RH and RS fuel ashes compared to wood fuel ash. Among the RS and RH fuel ashes, RH fuel ash has higher $\mathrm{K}_{2} \mathrm{O}+\mathrm{P}_{2} \mathrm{O}_{5}+\mathrm{SO}_{3}+\mathrm{Cl}_{2} \mathrm{O}$ in its inorganic composition. Figure $2 \mathrm{~b}$ was defined based on empirical findings regarding ash melting tendencies of dedicated fuel assortments and can be divided into three distinct sections with low $\left(<1100^{\circ} \mathrm{C}\right)$, medium $\left(1100-1300^{\circ} \mathrm{C}\right)$ and high $\left(>1300^{\circ} \mathrm{C}\right)$ initial deformation ash fusion temperature (DT) [184]. RH is located close to the area associated with high DT, Figure 2b. Accordingly, it is expected that RH shows low melting tendency during the combustion process. In contrast, RS is located near the area associated with low DT; therefore, it is anticipated that RS shows a higher melting tendency during the combustion process than RH. However, some data points in Figure $2 \mathrm{~b}$ are outside of the defined areas for which ash melt investigations are available, and it indicates some research gaps in knowledge. Therefore, scientific work must be carried out here to close the gaps.

According to Table 1 and Figure $2 b$, the silicon content of both RH and RS is high and suitable ash melting temperatures can be expected. However, there are several strategies to improve the purity of biogenic silica, which are discussed in Section 3. 


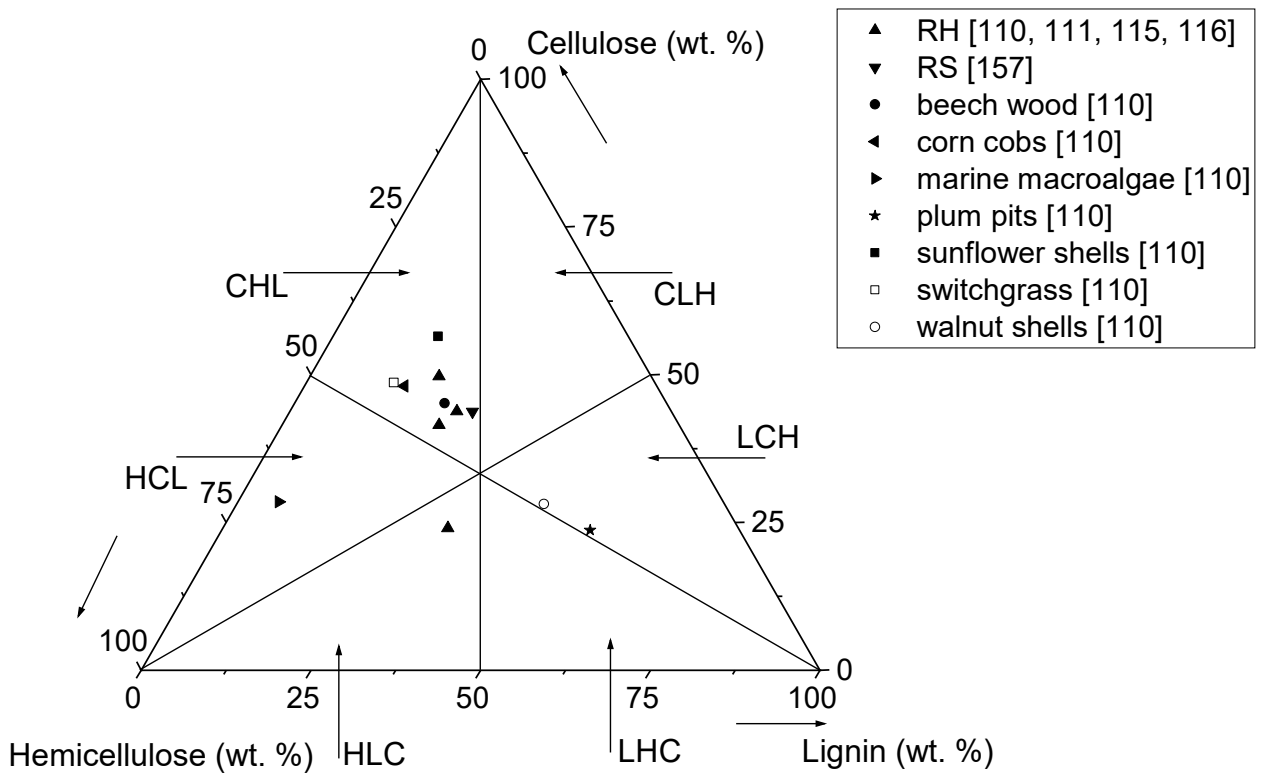

(a)

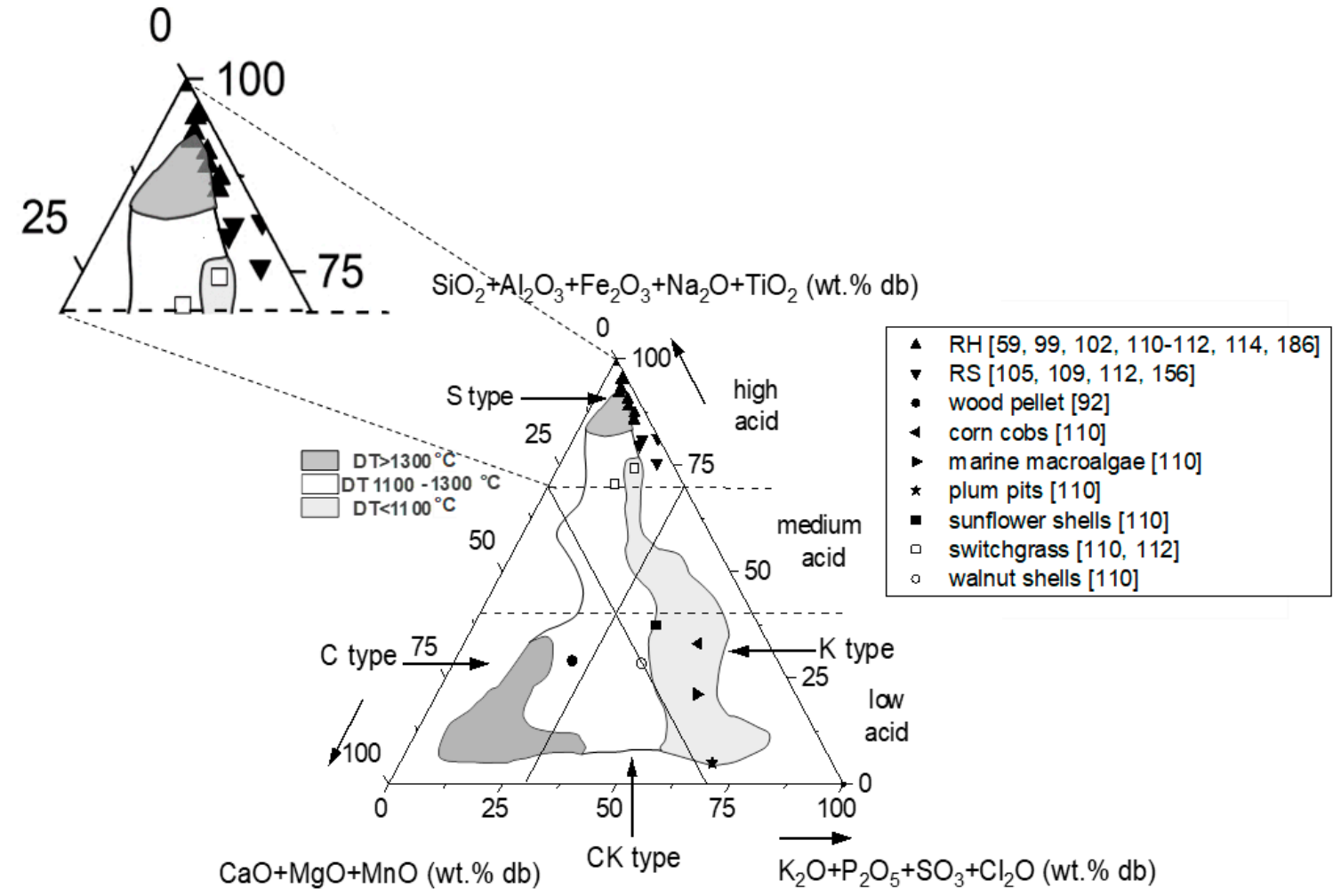

(b)

Figure 2. Biomass classification systems based on data from (a) organic compositions; and (b) inorganic composition of the fuel ash and ash melting tendency (data were taken from [59,92,99,102,105,109-112, $114-116,156,157,186])$.

\section{Production of Biogenic Silica}

Biogenic silica should have a low carbon content and high purity in order to be used in synthesizing advanced materials and for solar applications $[50,51,53]$. High specific surface area 
(SSA) and pore volume are required for catalytic applications [53]. Furthermore, biogenic silica should also be amorphous with no slagging tendency for any applications. To optimize production of biogenic silica with high quality the following three steps may be addressed: (1) combustion of RH and RS, (2) additional pre-treatment of the raw materials and/or (3) post-treatment of RHA and RSA.

\subsection{Combustion of Rice Husk and Rice Straw}

During thermochemical processes, the temperature of the RH and RS is increased under either oxygen or air atmosphere (combustion, $\lambda \geq 1$ ), inert atmosphere such as nitrogen or argon (pyrolysis, $\lambda=0$ ), or with stoichiometric amounts of air, oxygen, or $\mathrm{CO}_{2}$ (gasification, $0<\lambda<1$ ) in order to decompose organic components. In general, combustion is typically applied to produce biogenic silica [20]. Therefore, the focus of the present work is on combustion of RH and RS.

For silica purity, temperature and residence time are two main influential factors. The purity of resulting silica increases by increasing the conversion temperature (CT) and residence time (RT) $[20,69,187,188]$. However, higher CT and RT can increase the risk of crystallization of the obtained biogenic silica [64,189]. According to Table 3, during the combustion process, the carbon content of RHA dramatically diminishes and the purity regarding residual carbon content sharply raises by increasing the $\mathrm{CT}$ from 300 to $600{ }^{\circ} \mathrm{C}$ [20]. By increasing the $\mathrm{CT}$, carbon content and silica purity remain around the same until $\mathrm{SiO}_{2}$ crystallization takes place $[19,20,69]$. On the other hand, higher CT and RT reduce specific surface area (SSA) and total pore volume of RHA $[19,71]$. Often, this is attributed to the reduction in the carbon content and ash agglomeration, resulting in diminished porosity [189]. According to Table 3, close to $600{ }^{\circ} \mathrm{C}$, SSA and pore volume strongly depend on the $\mathrm{CT}$, and they drastically decrease by increasing CT from 600 to $700{ }^{\circ} \mathrm{C}$ or above [19,71]. Therefore, to produce high quality silica, it seems that the optimum CT for combustion of untreated $\mathrm{RH}$ is around $600{ }^{\circ} \mathrm{C}$. The quality of the resulting biogenic silica also depends on the combustion technology $[179,190]$.

Sufficient air flow rate is required for complete combustion in order to produce pure biogenic silica; otherwise, the resulting ash will contain unburned carbon [67]. The heating rate (HR) during combustion also plays an important role in the quality of the remaining ash [54,188,191,192]. The purity of the silica and consequently the brightness of the resulting ash deteriorate when HR increases, although pore volume and SSA of the remaining ash increase at the same time [54,192].

Usually, a multi-step decomposition of RH and RS has been applied in lab-scale studies to obtain high purity biogenic silica with high SSA and low carbon $[72,98,193]$. For the decomposition of the individual macromolecules cellulose, hemicellulose, and lignin, as described in Section 2, different temperatures are used $[72,98,100,193,194]$. This strategy guarantees amorphous structure of the resulting silica since the maximum temperature never exceeds crystallization temperature [72]. The range of crystallization temperature is defined in Section 3.2. However, upscaling of such time-consuming sequential combustion processes at industrial and bench-scales is not feasible. A sequential combustion process can also be designed by pyrolysis of $\mathrm{RH}$ followed by an oxidization process (combustion). This strategy was shown to produce amorphous silica at low CTs with silica purity higher than $99.9 \mathrm{wt} \%$ with a very low carbon content [195]. Table 3 summarizes the result of different studies in the field of biogenic silica production using combustion of RH.

In conclusion, quality of biogenic silica can be adjusted by combustion parameters such as CT, RT and heating rate. To achieve purities exceeding approx. $97.2 \mathrm{wt} \%$, further purification strategies have to be employed. 
Table 3. Combustion of RH to obtain pure biogenic silica.

\begin{tabular}{|c|c|c|c|c|c|}
\hline $\begin{array}{l}\text { Input Material, Source, } \\
\text { Silica Content in Fuel Ash }\end{array}$ & Combustion Process & Exp. Technique & Scale & Main Findings & Reference \\
\hline $\begin{array}{l}\text { Material: RH } \\
\text { Source: Riceland Foods, } \\
\text { Arkansas in the US }{ }^{1} \text {. } \\
\text { Silica content: N.R. }\end{array}$ & $\begin{array}{l}\text { RH was combusted at different temperatures } \\
\left(700,750,800,850,900, \text { and } 950^{\circ} \mathrm{C}\right) \\
\text { Atmosphere: air }\end{array}$ & TORBED reactor & $\begin{array}{l}\text { The reactor used was } 400 \\
\mathrm{~mm} \text { in diameter, and average } \\
\text { fuel feed rate was } 26.5 \mathrm{~kg} / \mathrm{h} \text {. }\end{array}$ & $\begin{array}{l}\text { Resulting RHA had silica purity between } 95.2 \text { and } 96.7 \mathrm{wt} \% \text {. With low reactor } \\
\mathrm{RT}^{2} \text { of }<10 \mathrm{~min}, \mathrm{RHA} \text { crystallization started at } 9500^{\circ} \mathrm{C} \text {. Loss of ignition (LOI) } \\
\text { decreased from } 1.8 \text { to } 1.0 \mathrm{wt} \% \text { by increasing CT } \mathrm{CT}^{3} \text { rrom } 700 \text { to } 900{ }^{\circ} \mathrm{C} \text {. } \\
\text { Furthermore, by raising CT from } 700 \text { to } 900^{\circ} \mathrm{C}, \mathrm{SSA}^{4}, \text { pore volume and } \\
\text { average pore radius decreased from } 37 \text { to } 6 \mathrm{~m}^{2} / \mathrm{g}, 0.11 \text { to } 0.02 \mathrm{~cm}^{3} / \mathrm{g} \text {, and } 1.9 \text { to } \\
1.2 \mathrm{~nm} \text {, respectively. }\end{array}$ & $\begin{array}{l}\text { Blissett et al., } \\
2017 \text { [19] }\end{array}$ \\
\hline $\begin{array}{l}\text { Material: RH } \\
\text { Source: Heilongiiang } \\
\text { province, China. } \\
\text { Silica content: N.R. }\end{array}$ & $\begin{array}{l}\text { RH was put in the furnace at } 600,700,800, \text { or } \\
900^{\circ} \mathrm{C} \text { for } 30 \text { min. Atmosphere: air }\end{array}$ & Muffle furnace & Lab-scale & $\begin{array}{l}\text { Silica purity in RHA obtained at } 600^{\circ} \mathrm{C} \text { was } 92.1 \mathrm{wt} \% \text {. Both pore volume and } \\
\text { SSA of the RHA drastically declined by increasing CT from } 600 \text { to } 700{ }^{\circ} \mathrm{C} \text {, and } \\
\text { then slowly decreased by raising CT from } 700 \text { to } 900{ }^{\circ} \mathrm{C} \text {. SSA of the RHA was } \\
145 \text { and } 25 \mathrm{~m}^{2} / \mathrm{g} \text { at } 600 \text { and } 700^{\circ} \mathrm{C} \text {, respectively. }\end{array}$ & $\begin{array}{l}\text { Chen et al., } \\
2017 \text { [71] }\end{array}$ \\
\hline $\begin{array}{l}\text { Material: RH } \\
\text { Source: state of Rio Grande } \\
\text { do Sul, Brazil. } \\
\text { Silica content: N.R. }\end{array}$ & $\begin{array}{c}\text { Combustion at around } 700^{\circ} \mathrm{C} \\
\text { Atmosphere: air }\end{array}$ & $\begin{array}{l}\text { RH was combusted in } \\
\text { three different } \\
\text { combustion } \\
\text { technologies: moving } \\
\text { grate reactor, } \\
\text { suspension/entrained } \\
\text { combustion chamber, } \\
\text { and fluidized bed. }\end{array}$ & $\begin{array}{l}\text { The output electricity power } \\
\text { capacity of the moving grate } \\
\text { reactor, suspension/ } \\
\text { entrained combustion } \\
\text { chamber, and fluidized bed } \\
\text { were } 3.8,12.5 \text {, and } 5 \mathrm{MWh} \text {, } \\
\text { respectively. }\end{array}$ & $\begin{array}{l}\text { Quality of the RHA (silica purity and carbon content, and the structure of the } \\
\text { ash) was affected by combustion technologies. } \\
\text { The highest silica purity }(96.7 \mathrm{wt} \%) \text { and the lowest } \mathrm{LOI}(2.96 \%) \text { were obtained } \\
\text { using fluidized bed technology. } \\
\text { Consequently, SSA was } 11,27 \text { and } 39 \mathrm{~m}^{2} / \mathrm{g} \text { in fluidized bed, } \\
\text { suspension/entrained combustion chamber, and moving grate reactor, } \\
\text { respectively. } \\
\text { XRD results indicated that the ashes from suspension/entrained combustion } \\
\text { chamber are completely amorphous, while products from moving grate reactor } \\
\text { and fluidized bed were completely or partially crystalline, respectively. }\end{array}$ & $\begin{array}{l}\text { Fernandes et al., } \\
2016[179]\end{array}$ \\
\hline $\begin{array}{l}\text { Material: RH } \\
\text { Source: Harbin, Heilongiiang } \\
\text { province, China. } \\
\text { Silica content: N.R. }\end{array}$ & $\begin{array}{l}\text { Heating } \mathrm{RH} \text { at } 5 \mathrm{~K} / \mathrm{min} \text { to } 600^{\circ} \mathrm{C} \text { for } 1 \text { or } 2 \mathrm{~h} \text {, } \\
\text { or to } 700^{\circ} \mathrm{C} \text { for } 1 \mathrm{~h} \text {. } \\
\text { Atmosphere: air }\end{array}$ & $\begin{array}{l}\text { Muffle furnace with } \\
\text { half-opened door for } \\
\text { airflow control. }\end{array}$ & Lab-scale & $\begin{array}{l}\text { Silica purity was } 92.09,93.00 \text {, and } 93.42 \mathrm{wt} \% \text {, LOI was } 1.52,1.48 \text { and } 3.24 \text {, and } \\
\mathrm{SSA} \text { was } 86,90 \text { and } 27 \mathrm{~m}^{2} / \mathrm{g} \text { for combustion at } 600{ }^{\circ} \mathrm{C} \text { for } 1 \text { and } 2 \mathrm{~h} \text {, and } \\
\text { combustion at } 7000^{\circ} \mathrm{C} \text { for } 1 \mathrm{~h} \text {, respectively. } \\
\text { Results indicated that RHA obtained at } 700{ }^{\circ} \mathrm{C} \text { was darker than } \mathrm{RHA} \text { obtained } \\
\text { at } 6000^{\circ} \mathrm{C} \text {. It was interpreted that when conversion temperature is higher than } \\
\text { decomposition temperature of potassium oxide in the fuel sample } \mathrm{K}_{2} \mathrm{O} \text { melts } \\
\text { and entraps the unburned carbon content. Therefore, remaining carbon in the } \\
\text { ash is high for RHA obtained at } 700^{\circ} \mathrm{C} \text { compared to the RHA produced at } \\
600^{\circ} \mathrm{C} \text {. }\end{array}$ & $\begin{array}{l}\text { Bie et al., } 2015 \\
{[69]}\end{array}$ \\
\hline $\begin{array}{l}\text { Material: RH } \\
\text { Source: Quzhou, Zhejiang, } \\
\text { China. } \\
\text { Silica content: N.R. }\end{array}$ & $\begin{array}{l}\text { RH was combusted at } 5 \mathrm{~K} / \mathrm{min} \text { from room } \\
\text { temperature to } 300 \text { to } 750^{\circ} \mathrm{C} \text { with RT of } 2 \mathrm{~h} \text {. } \\
\text { Atmosphere: air }\end{array}$ & Muffle furnace & Lab-Scale & $\begin{array}{l}\text { Silica purity of RHA increased from } 29.7 \mathrm{wt} \% \text { at } 300{ }^{\circ} \mathrm{C} \text { to } 94.1 \text { and } 96.3 \mathrm{wt} \% \text { at } \\
600 \text { and } 750^{\circ} \mathrm{C} \text {, respectively. Consequently, the carbon content decreased from } \\
48.8 \mathrm{wt} \% \text { at } 300^{\circ} \mathrm{C} \text { to } 5.4 \text { and } 3.2 \mathrm{wt} \% \text { at } 600 \text { and } 750^{\circ} \mathrm{C} \text {, respectively. The } \\
\text { structure of RHA remained amorphous up to } 6000^{\circ} \mathrm{C} \text {, and then a crystalline } \\
\text { crystobalite peak appeared in XRD patterns. Results showed that SSA, total } \\
\text { pore volume, micropore and mesopore volumes decrease by raising the CT. For } \\
\text { instance, SSA decreased from } 60 \text { to } 6 \mathrm{~m}^{2} / \mathrm{g} \text { by increasing the } \mathrm{CT} \text { from } 300 \text { to } \\
750{ }^{\circ} \mathrm{C} \text {. }\end{array}$ & $\begin{array}{l}\text { Chen et al., } \\
2011[20]\end{array}$ \\
\hline $\begin{array}{l}\text { Material: RH } \\
\text { Source: N.R. } \\
\text { Silica content: N.R. }\end{array}$ & $\begin{array}{l}\text { Combustion of RH was investigated with } \\
\text { slow and fast heating rates. In slow heating, } \\
\text { the furnace was heated from room } \\
\text { temperature to } 700^{\circ} \mathrm{C} \text { at } 5 \mathrm{~K} / \mathrm{min} \text { with RT of } \\
4 \mathrm{~h} \text {. In fast heating, RH was transferred to the } \\
\text { furnace at } 700^{\circ} \mathrm{C} \text { for } 3 \mathrm{~h} \text {. } \\
\text { Atmosphere: N.R. }\end{array}$ & $\begin{array}{l}\text { Muffle furnace with } \\
\text { steel trays with size of } \\
15 \times 10 \times 2.5 \mathrm{~cm} \text {. }\end{array}$ & Lab-scale & $\begin{array}{l}\text { The purity of biogenic silica and the carbon content were around the same in } \\
\text { both RHAs obtained from slow and fast heating. The value of the silica purity } \\
\text { for slow and fast heating rates was } 90.20 \text { and } 89.80 \mathrm{wt} \% \text {, respectively; whereas, } \\
\text { the carbon content was around } 4.2 \mathrm{wt} \% \text { for both heating rates. However, } \\
\text { brightness of the RHA obtained in slow heating was higher than the brightness } \\
\text { for the fast heating rate. }\end{array}$ & $\begin{array}{l}\text { Krishnarao et al., } \\
2001[188]\end{array}$ \\
\hline
\end{tabular}

${ }^{1}$ The rice husk provided was parboiled and dried prior to shipping. ${ }^{2}$ RT: residence time ${ }^{3}$ CT: conversion temperature ${ }^{4}$ SSA: specific surface area. 


\subsection{Combination of Fuel Pre-Treatment with Combustion}

Since RH and RS are composed of organic matter such as cellulose, hemicellulose, and lignin as well as inorganic matter $[50,53,91]$, washing or leaching the fuel samples with specified chemical solutions can alter the organic and inorganic composition of RH and RS as well as the composition of resulting RHA and RSA. Ash-forming elements can be divided into water soluble, acid soluble and insoluble parts $[71,196,197]$. In general, alkali metals (potassium, sodium) belong to the water soluble portion of the ash while alkaline earth metals (calcium, magnesium) and manganese are acid soluble. Silicon, aluminum and iron species remain insoluble. Pre-treatment of RS can change the concentration of ash-forming elements such as potassium. Consequently, the location of RS in Figure $2 b$ can be adjusted to a position associated with higher DT. Figure 3 shows the melting behavior of the RS and tap-water washed RS during the combustion process. Accordingly, washing with water can prevent melting and slag formation during combustion of RS [198].

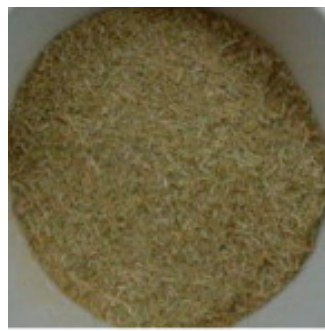

(a)

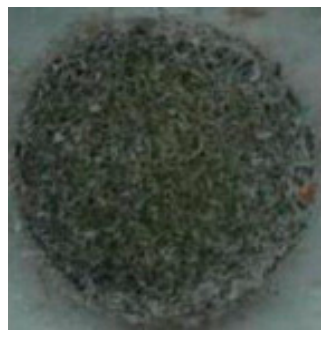

(b)

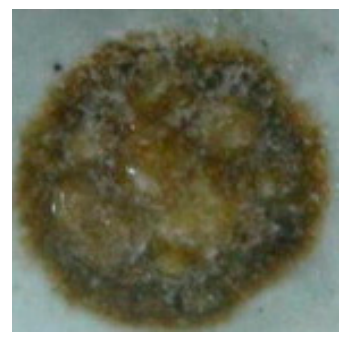

(c)

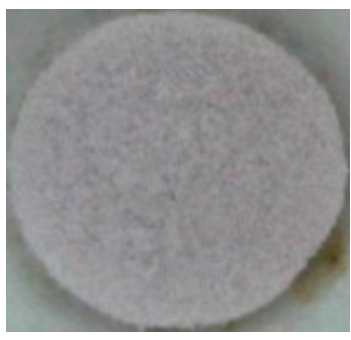

(d)

Figure 3. Rice straw: (a) before combustion; (b) untreated RS combusted at 700-800 ${ }^{\circ} \mathrm{C}$; (c) untreated RS combusted at $900-1000{ }^{\circ} \mathrm{C}$; (d) washed RS combusted at 900-1000 ${ }^{\circ} \mathrm{C}$ [198]. Reprinted from Waste Management, 33, N. Said, T. Bishara, A. García-Maraver, M. Zamorano, Effect of water washing on the thermal behavior of rice straw, 2250-2256, Copyright (2013), with permission from Elsevier.

As illustrated by Figure 4, the effect of pre-treatment is more prominent in RS than in RH. According to Figure 4, simple water washing can change the position of RS from close to low melting temperature region to a high melting temperature part. This shift is far less pronounced for $\mathrm{RH}$, which shows that washing does not have a drastic effect on the melting tendency of RH. In Figure 4, data points for original and treated RH and RS are outside of the defined areas and it shows gaps in knowledge, which should be closed in future studies. Table 4 provides an overview of pre-treatment strategies which were used in Figure 4.

Table 4. Summary of fuel washing strategies for RH and RS used in Figure 4 [102,105,109].

\begin{tabular}{cr}
\hline Symbol & Fuel Pre-Treatment Strategy \\
\hline WRH 1 & RH was soaked in distilled water. No details have been reported for water washing. \\
\hline WRS 1 & RS was collected after having received a total of $451 \mathrm{~mm} / \mathrm{m}^{2}$ of rain. \\
\hline WRS 2 & Laboratory washed, $100 \mathrm{~g}$ whole straw, hand sprayed for $1 \mathrm{~min}$ with tap water. \\
\hline WRS 3 & Laboratory washed, $100 \mathrm{~g}$ whole straw, submerged in 7 liters of distilled water for $24 \mathrm{~h}$. \\
\hline WRS 4 & RS was collected after having received a total of $65 \mathrm{~mm}$ of rain (after first rain). \\
\hline
\end{tabular}




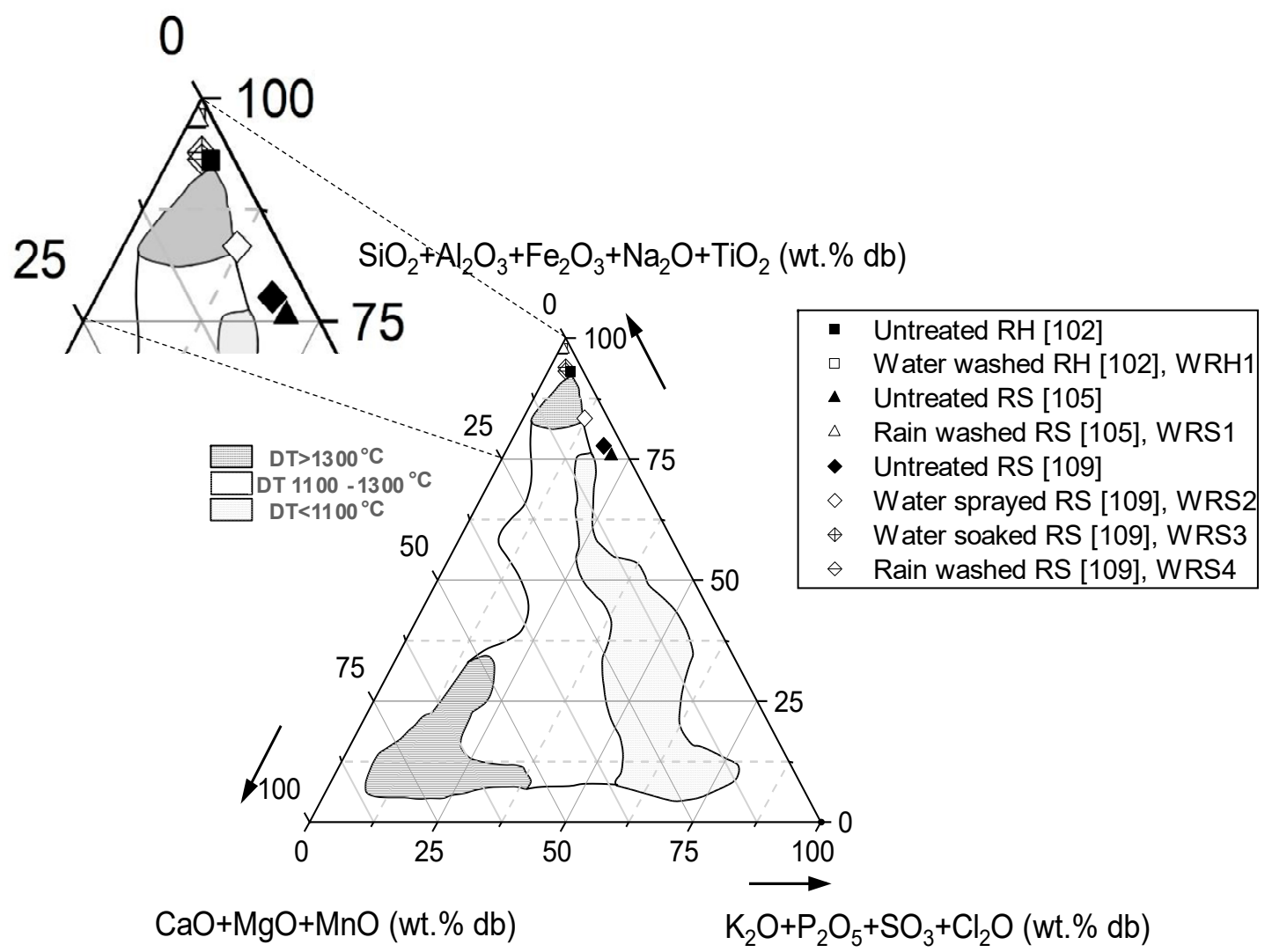

Figure 4. The effect of fuel washing strategies on the melting tendency of RH and RS (data were taken from $[102,105,109])$.

Another advantage of fuel pre-treatment is that it can reduce the risk of crystallization in the resulting biogenic silica $[67,71,187,189,199]$. Pre-treated RHs remained amorphous up to $1000{ }^{\circ} \mathrm{C}$ [200]. In contrast, untreated RH crystallized at temperatures between 600 and $900{ }^{\circ} \mathrm{C}$ depending on source of the RH and combustion conditions $[19,20,66,189]$. Pre-treatment was also shown to improve physisorption and pore structure characteristics of biogenic silica $[53,71,73,100,200,201]$. Accordingly, both SSA and pore volume are improved by pre-treatment of the fuels (Table 5), thus being a prerequisite for catalytic applications of biogenic silica.

Table 5 summarizes the results of combustion experiments performed with pre-treated RH and RS.

According to Table 3, the maximum silica purity, SSA and pore volume are about $97.2 \mathrm{wt} \%$, $220 \mathrm{~m}^{2} / \mathrm{g}$ and $0.26 \mathrm{~cm}^{3} / \mathrm{g}$, respectively, among the RHA obtained from combustion of untreated RH. According to Table 5, however, fuel pre-treatment improves purity of up to $99.77 \mathrm{wt} \%$, increases SSA of $353 \mathrm{~m}^{2} / \mathrm{g}$ and doubling of the pore volume $\left(0.52 \mathrm{~cm}^{3} / \mathrm{g}\right)$. The most effective fuel pre-treatment to remove impurities and to obtain biogenic silica with purity higher than $99.7 \mathrm{wt} \%$ has been reported by Umeda at al. [187]. In this strategy, RH was leached with $5 \mathrm{wt} \%$ of citric acid solution at $80{ }^{\circ} \mathrm{C}$ for $1 \mathrm{~h}$ followed by combustion in air atmosphere at $800{ }^{\circ} \mathrm{C}$ for $30 \mathrm{~min}$. For further purification, ash post-treatment techniques may be applied, which are discussed in Section 3.3.

\subsection{Combination of Fuel Pre-Treatment, Ash Post-Treatment and Combustion of Rice Husk and Rice Straw}

Thermal treatment or acid leaching of RHA and RSA are considered a post-treatment. Table 6 provides an overview of ash post-treatments that were applied in combination with fuel pre-treatment and combustion of RH and RS. 
Table 5. Combined fuel pre-treatment and combustion to obtain pure biogenic silica from RH and RS.

\begin{tabular}{|c|c|c|c|c|c|c|}
\hline $\begin{array}{l}\text { Input Material, Source, } \\
\text { Silica Content in } \\
\text { Fuel Ash }\end{array}$ & & Fuel Pre-Treatment & Combustion Process & Scale & Main Findings & Reference \\
\hline $\begin{array}{l}\text { Material: RH and RS } \\
\text { Source: Cambodia, Italy } \\
\text { and Vietnam } \\
\text { Silica content of the fuel } \\
\text { ash: } 50.7-83.2 \mathrm{wt} \% \text {. }\end{array}$ & (1) & $\begin{array}{l}100 \mathrm{~g} \text { of RH or RS was washed with water } \\
\text { (solid-to-liquid ratio } 1: 13 \mathrm{wt} \text {. /wt.) and agitated in a } \\
\text { flask under stirring conditions ambient temperature } \\
\text { for one day followed by filtration. } \\
\text { Water-washed RH leached with } 3.25 \mathrm{M} \text { citric acid } \\
\text { (solid-to-liquid ratio } 1: 13 \text { ) at } 50^{\circ} \mathrm{C} \text { for one day } \\
\text { followed by filtration. } \\
\text { Acid-leached RH was washed with water and dried for } \\
\text { one day at } 50^{\circ} \mathrm{C} \text {. }\end{array}$ & $\begin{array}{l}\text { Multi-step sequential } \\
\text { combustion at a heating rate } \\
\text { of } 10 \mathrm{~K} / \mathrm{min}: 310^{\circ} \mathrm{C} \text { for } \\
30 \mathrm{~min}, 4500^{\circ} \mathrm{C} \text { for } 60 \mathrm{~min}, \\
510^{\circ} \mathrm{C} \text { for } 210 \mathrm{~min} \text { and finally, } \\
600^{\circ} \mathrm{C} \text { for } 30 \mathrm{~min} . \\
\text { Atmosphere: air }\end{array}$ & $\begin{array}{l}\text { Muffle } \\
\text { furnace }\end{array}$ & $\begin{array}{l}\text { Both RHA and RSA showed silica purity higher than } 99 \mathrm{wt} \% \text {. Italian RHA } \\
\text { had the highest purity which was around } 99.7 \mathrm{wt} \% \text {. SSA } \mathrm{S}^{1} \text { was higher than } \\
260 \mathrm{~m}^{2} / \mathrm{g} \text { for all RHAs, and the highest value was for Cambodian RHA } \\
\left(300 \mathrm{~m}^{2} / \mathrm{g} \text {. As the maximum processing temperature was lower than }\right. \\
\text { normal crystallization temperature, all RHAs and RSA were completely } \\
\text { amorphous. It was concluded that water washing, which is swelling of the } \\
\text { cell walls and pre-hydrolysis the carbohydrates, allow citric acid to reach } \\
\text { and contact with the inner parts and as a result, remove the inner inorganic } \\
\text { matter effectively. Regardless of the silicon purity in the starting material, } \\
\text { the process had a potential to produce biogenic silica with almost } \\
\text { uniform quality. }\end{array}$ & $\begin{array}{l}\text { Schneider et al., } \\
2018 \text { [72] }\end{array}$ \\
\hline $\begin{array}{l}\text { Material: RH } \\
\text { Source: N.R. } \\
\text { Silica content of the fuel } \\
\text { ash: N.R. }\end{array}$ & (1) & $\begin{array}{l}\text { RH was washed with deionized water three times and } \\
\text { dried at } 60^{\circ} \mathrm{C} \text { for one day. } \\
\text { Sulfuric acid, hydrogen chloride, oxalic acid, and an } \\
\text { ionic liquidid (1-butyl-3-methylimidazolium hydrogen } \\
\text { sulfate) were used as follows: Sulfuric acid treatment: } \\
\mathrm{RH} \text { was immersed in } 72 \% \text { sulfuric acid at } 30^{\circ} \mathrm{C} \text { for } 1 \mathrm{~h} \text {. } \\
\text { Then, concentration of the acid was adjusted to } 4 \% \\
\text { using deionized water, and then RH was incubated at } \\
121^{\circ} \mathrm{C} \text { for } 1 \mathrm{~h} \text {. Afterwards, the acid was removed and } \\
\text { washed with hot deionized water. Hydrogen chloride } \\
\text { treatment: } \mathrm{RH} \text { was immersed in } 10 \mathrm{wt} \% \text { hydrogen } \\
\text { chloride and incubated at } 90^{\circ} \mathrm{C} \text { for } 1 \mathrm{~h} \text {. Then, it was } \\
\text { washed with deionized water. Oxalic acid treatment: } \\
\text { Reacting RH in } 1 \mathrm{M} \text { of the acid under a carbon dioxide } \\
\text { atmosphere with } 20 \text { psi at } 2000^{\circ} \mathrm{C} \text { for } 3 \mathrm{~h} \text {. Then, it was } \\
\text { washed with deionized water. } \\
\text { Washed residue was dried at } 60^{\circ} \mathrm{C} \text { for one day. }\end{array}$ & $\begin{array}{l}\text { Combustion at } 800^{\circ} \mathrm{C} \text {. } \\
\text { Although it was called } \\
\text { pyrolysis in the paper, but } \\
\text { there is no indication for it. } \\
\text { Furthermore, the results were } \\
\text { compared with combustion } \\
\text { studies. } \\
\text { Atmosphere: N.R. }\end{array}$ & $\begin{array}{l}\text { Muffle } \\
\text { furnace }\end{array}$ & $\begin{array}{l}\text { XRD patterns showed that all RHAs were amorphous. Silica purity of RHA } \\
\text { increased using fuel pre-treatment. The value for untreated samples and } \\
\text { those treated with sulfuric acid, hydrogen chloride, oxalic acid, and ionic } \\
\text { liquid was } 94.7,99.6,98.0 \text { and } 99.5 \mathrm{wt} \% \text {, respectively, whereas the carbon } \\
\text { content for these ashes was around the same (between } 0.02 \text { and } 0.08 \mathrm{wt} \% \text {. } \\
\text { Results indicated that ashes obtained from treated RH had no potassium } \\
\text { content while untreated sample had around } 1.7 \mathrm{wt} \% \text { of } \mathrm{K}_{2} \mathrm{O} \text {. } \mathrm{N}_{2} \text { sorption } \\
\text { data showed that SSA and pore volume of untreated samples and treated } \\
\text { with sulfuric acid, hydrogen chloride, oxalic acid, and ionic liquid were } 99 \text {, } \\
85,66,71 \text { and } 185 \mathrm{~m}^{2} / \mathrm{g} \text { and } 0.17,0.22,0.18,0.21 \text { and } 0.41 \mathrm{~cm}^{3} / \mathrm{g} \text {, } \\
\text { respectively. }\end{array}$ & $\begin{array}{c}\text { Lee et al., } 2017 \\
\text { [91] }\end{array}$ \\
\hline $\begin{array}{l}\text { Material: RH } \\
\text { Source: Heilongjiang } \\
\text { province, China. } \\
\text { Silica content of the fuel } \\
\text { ash: N.R. }\end{array}$ & $\begin{array}{l}(1) \\
(2)\end{array}$ & $\begin{array}{l}\text { Original RH was dried at } 105^{\circ} \mathrm{C} \text { for } 2 \mathrm{~h} \text { to completely } \\
\text { remove moisture. } \\
30 \mathrm{~g} \text { of } \mathrm{RH} \text { was added to } 500 \mathrm{~mL} \text { of hydrochloric, } \\
\text { sulfuric, or acetic acid solution for } 1 \mathrm{~h} \text { at } \\
\text { room temperature. } \\
\text { solid residue was filtered and washed with deionized } \\
\text { water several times to reach a neutral condition, and } \\
\text { then it was dried at } 105^{\circ} \mathrm{C} \text { for } 2 \mathrm{~h} \text { in an oven. }\end{array}$ & $\begin{array}{l}\text { As-received RH and } \\
\text { acid-leached RH (LRH) were } \\
\text { burned at } 600,700,800 \text {, and } \\
900{ }^{\circ} \mathrm{C} \text { for } 30 \text { min while air } \\
\text { flow was continuously fed in } \\
\text { during the combustion } \\
\text { process. } \\
\text { Atmosphere: air }\end{array}$ & $\begin{array}{l}\text { Muffle } \\
\text { furnace }\end{array}$ & $\begin{array}{l}\text { Result of inductively coupled plasma-optical emission spectrometry } \\
\text { (ICP-OES) showed that silica purity in acid leached RHA (LRHA) samples, } \\
\text { which were obtained at } 600{ }^{\circ} \mathrm{C} \text {, was in the range of } 96.5-98.6 \mathrm{wt} \% \text {. This } \\
\text { range is much higher than the silica purity of untreated RHA } 92.1 \mathrm{wt} \% \text {. } \\
\text { Furthermore, } \mathrm{K}_{2} \mathrm{O} \text { content was around } 0.2-0.6 \mathrm{wt} \% \text { in LRHAs; while, it was } \\
4.0 \mathrm{wt} \% \text { in untreated RHA. } \\
\text { Both pore volume and SSA of the LRHA were higher than these values of } \\
\text { original RHA. The maximum value of the SSA and pore volume obtained } \\
\text { from sulfuric acid leached ash at } 60{ }^{\circ} \mathrm{C} \text {, which were } 237 \mathrm{~m}^{2} / \mathrm{g} \text { and } 0.084 \\
\mathrm{~cm}^{3} / \mathrm{g} \text {, whereas these parameters were } 145 \mathrm{~m}^{2} / \mathrm{g} \text { and } 0.001 \mathrm{~cm}{ }^{3} / \mathrm{g} \text { in } \\
\text { untreated RHA, respectively. It is worth mentioning that the reported pore } \\
\text { volumes are not reliable, as the authors did not measured the complete } \\
\text { isotherm for their calculation. }\end{array}$ & $\begin{array}{c}\text { Chen et al., } 2017 \\
\text { [71] }\end{array}$ \\
\hline
\end{tabular}


Table 5. Cont.

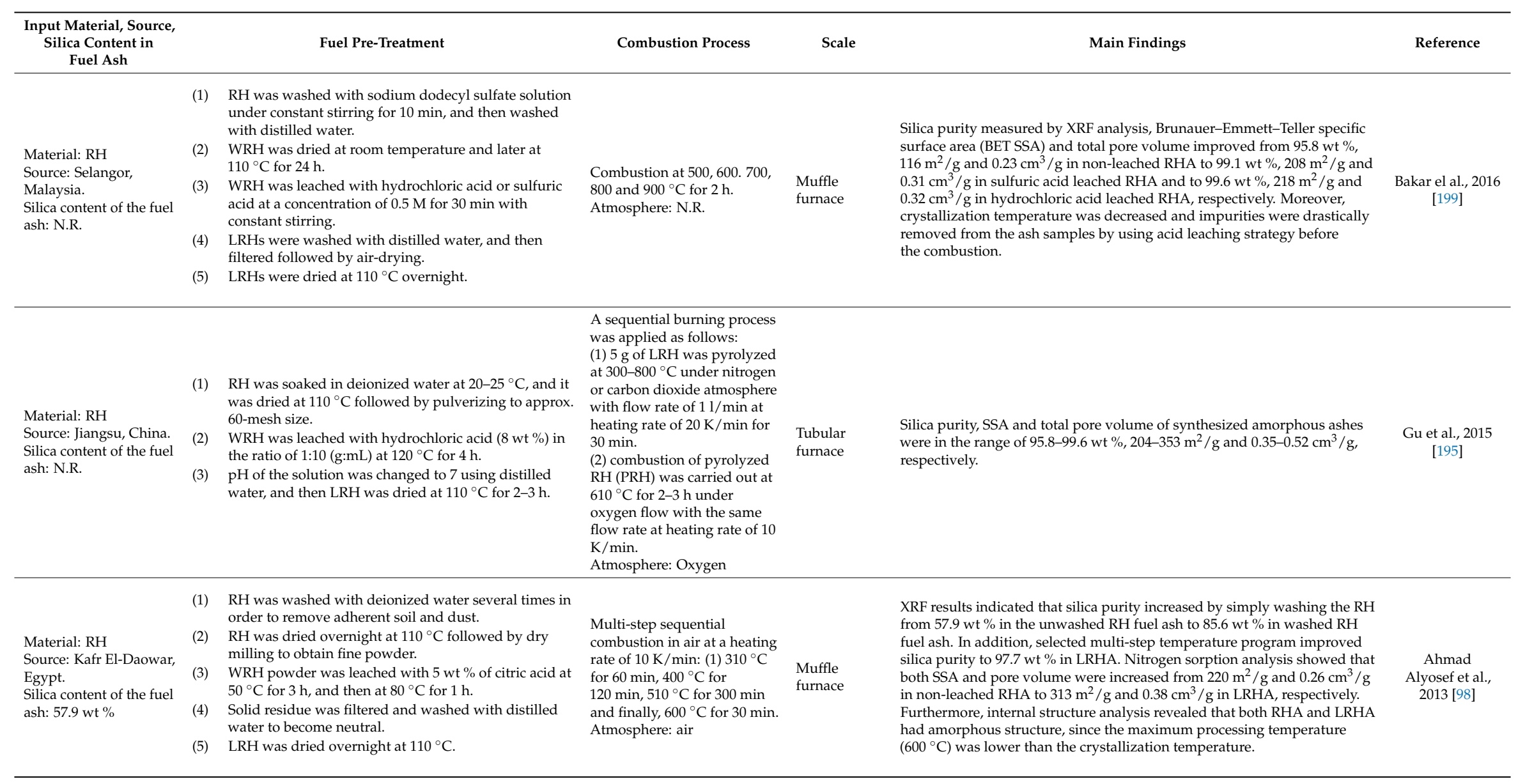


Table 5. Cont.

\begin{tabular}{|c|c|c|c|c|c|}
\hline $\begin{array}{l}\text { Input Material, Source, } \\
\text { Silica Content in } \\
\text { Fuel Ash }\end{array}$ & Fuel Pre-Treatment & Combustion Process & Scale & Main Findings & Reference \\
\hline $\begin{array}{l}\text { Material: RS } \\
\text { Source: different } \\
\text { regions in Spain } \\
\text { and Egypt. } \\
\text { Silica content of the fuel } \\
\text { ash: N.R. }\end{array}$ & $\begin{array}{l}\text { (1) RS was cut to } 10 \mathrm{~cm} \text { and washed with tap water } \\
\text { following by drying at } 105^{\circ} \mathrm{C} \text { to a constant weight. } \\
\text { (2) Size of the unwashed RS and washed RS (WRS) was } \\
\text { reduced to } 0.5 \mathrm{~mm} \text {. }\end{array}$ & $\begin{array}{l}\text { RS and WRS was heated up } \\
\text { from } 30 \text { to } 1000^{\circ} \mathrm{C} \text { at a } \\
\text { heating rate of } 10 \mathrm{~K} / \mathrm{min} \text {. Air } \\
\text { flow rate was } 100 \mathrm{~mL} / \mathrm{min} \text {. } \\
\text { Atmosphere: air }\end{array}$ & TG-DSC & $\begin{array}{l}\text { Simply washing of RS with tap water reduced } \mathrm{Na}, \mathrm{K}, \mathrm{Mg}, \mathrm{P}, \mathrm{S} \text { and } \mathrm{Cl} \\
\text { elements in the ashes with the removal percentages of } 35.6-60.0,26.1-49.5 \text {, } \\
0.0-38.8,0.0-34.8,25.5-59.4 \text { and } 59.0-87.0 \% \text {, respectively. As a result, water } \\
\text { washing controlled slag formation during the combustion of } \mathrm{RS} \text { from } \\
\text { different regions. }\end{array}$ & $\begin{array}{c}\text { Said et al., } 2013 \\
\text { [198] }\end{array}$ \\
\hline $\begin{array}{l}\text { Material: RH } \\
\text { Source: Wuyunjing, } \\
\text { China. } \\
\text { Silica content of the fuel } \\
\text { ash: N.R. }\end{array}$ & $\mathrm{RH}$ was leached with deionized water at $25 \pm 1{ }^{\circ} \mathrm{C}$ for $4 \mathrm{~h}$. & $\begin{array}{l}\text { RH and WRH was calcined } \\
\text { and held at a maximum } \\
\text { temperature }(600,700 \text { and } \\
\left.800^{\circ} \mathrm{C}\right) \text { for } 0.5,1.5,2.5 \text { and } 3.5 \\
\text { h. } \\
\text { Atmosphere: air }\end{array}$ & N.R. & $\begin{array}{l}\text { The effect of calcination parameters }\left(\mathrm{CT}^{2} \text { and } \mathrm{RT}^{3}\right) \text { on RHA content was } \\
\text { studied in RH and WRH. It was shown that the ash content decreases by } \\
\text { increasing CT in both RH and WRH samples. That is because some of the } \\
\text { metallic elements show higher volatility at higher calcination temperatures. } \\
\text { Results indicated that in the original RH, ash content was dramatically } \\
\text { decreased by raising RT, which is because of the slow oxidation of carbon } \\
\text { residues in original RH. On the other hand, WRH had no change in ash } \\
\text { content when the RT is longer than } 1.5 \mathrm{~h} \text {, which implies no carbon residues } \\
\text { in RHA, and it was interpreted as an indication for pure silica production } \\
\text { from WRH. } \\
\text { It was shown that increasing the CT and RT decreases the SSA of the } \\
\text { WRHA, which is because of the agglomeration effect and diminishing } \\
\text { porosity of the ash. }\end{array}$ & $\begin{array}{c}\text { Shen et al., } 2011 \\
\text { [189] }\end{array}$ \\
\hline $\begin{array}{l}\text { Material: RH } \\
\text { Source: Niigata, Japan. } \\
\text { Silica content of the fuel } \\
\text { ash: N.R. }\end{array}$ & $\begin{array}{l}\text { (1) } 30 \mathrm{~g} \text { of RH was added into } 500 \mathrm{~mL} \text { of citric acid } \\
\text { solution with acid concentration of } 1 \text { to } 7 \mathrm{wt} \% \text { under } \\
\text { different stirring conditions. The temperature of the } \\
\text { solution was changed from } 25 \text { to } 80^{\circ} \mathrm{C} \text {. The time of the } \\
\text { stirring process was selected between } 15 \text { and } 120 \text { min } \\
\text { under rotating speed of } 960 \mathrm{rpm} \text {. } \\
\text { (2) Water rinsing was carried out using deionized water at } \\
20^{\circ} \mathrm{C} \text { for } 15 \text { min under stirrer condition. } \\
\text { (3) The solution was dried at } 373 \mathrm{~K} \text { for } 1 \mathrm{~h} \text { in a } \\
\text { muffle furnace. }\end{array}$ & $\begin{array}{l}\text { LRH was burned at } 800^{\circ} \mathrm{C} \\
\text { for } 30 \mathrm{~min} \text { under airflow rate } \\
\text { of } 0.42 \mathrm{~mL} / \mathrm{s} \text { using a small } \\
\text { air-compressor. } \\
\text { Atmosphere: air flow. }\end{array}$ & $\begin{array}{l}\text { Muffle } \\
\text { furnace }\end{array}$ & $\begin{array}{l}\text { XRF results indicated that leaching RH with citric acid solution and a } \\
\text { concentration over } 1 \mathrm{wt} \% \text { produces RHA with silica purity higher than } 99.5 \\
\text { wt } \% \text {, whereas silica purity of untreated RHA was } 97.2 \mathrm{wt} \% \text {. Potassium } \\
\text { oxide content was } 1.39 \mathrm{wt} \% \text { in untreated RHA. However acid leaching } \\
\text { process reduced its level into } 0.01-0.03 \mathrm{wt} \% \text { in LRHA samples. } \\
\text { Furthermore, it was shown that silica purity is not sensitive to concentration } \\
\text { of acid solution and temperature of acid leaching process, and only } 1 \mathrm{wt} \% \\
\text { of citric acid leaching at room temperature was enough to remove } \\
\text { potassium and carbon contents to produce pure biogenic silica. Maximum } \\
\text { silica purity was obtained from RH leached with } 5 \mathrm{wt} \% \text { of acid solution at } \\
80{ }^{\circ} \mathrm{C} \text {, which was } 99.77 \mathrm{wt} \% \text { (compared to } 99.47 \mathrm{wt} \% \text { upon leaching with } 1 \\
\mathrm{wt} \% \text { of citric acid at room temperature). } \\
\text { XRD patterns showed that acid leaching improves LRHA resistance to } \\
\text { crystallization. }\end{array}$ & $\begin{array}{c}\text { Umeda and } \\
\text { Kondoh } 2010 \\
\text { [187] }\end{array}$ \\
\hline $\begin{array}{l}\text { Material: RH } \\
\text { Source: Niigata, Japan. } \\
\text { Silica content of the fuel } \\
\text { ash: N.R. }\end{array}$ & $\begin{array}{l}\text { (1) } 20 \mathrm{~g} \text { of RH was immersed in } 500 \mathrm{~mL} \text { of citric acid and } \\
\text { sulfuric acid solution for } 15 \mathrm{~min} \text { with acid } \\
\text { concentration of } 5 \mathrm{wt} \% \text {, and it was kept at } 50^{\circ} \mathrm{C} \text {. } \\
\text { (2) Water rising treatment after leaching process was } \\
\text { repeated three and eight times. } \\
\text { (3) It was dried at } 100{ }^{\circ} \mathrm{C} \text { for } 1 \mathrm{~h} \text { in an electric furnace to } \\
\text { remove the acid. }\end{array}$ & $\begin{array}{l}\text { As-received RH and LRH } \\
\text { were burned in air }(150 \\
\mathrm{mL} / \mathrm{min} \text { ) at } 600-1150^{\circ} \mathrm{C} \text {. } \\
\text { Atmosphere: air }\end{array}$ & TG-DSC & $\begin{array}{l}\text { Results of XRF analysis showed that silica purity was improved from } 94.6 \text { in } \\
\text { untreated RHA to higher than } 99 \mathrm{wt} \% \text { in LRHA. Furthermore, LRHA with } \\
\text { lower metallic impurities remained amorphous until } 1050^{\circ} \mathrm{C} \text {, which is the } \\
\text { highest value published in literature. }\end{array}$ & $\begin{array}{l}\text { Umeda and } \\
\text { Kondoh, 2008 } \\
\text { [67] }\end{array}$ \\
\hline
\end{tabular}


Table 5. Cont.

\begin{tabular}{|c|c|c|c|c|c|c|}
\hline $\begin{array}{l}\text { Input Material, Source, } \\
\text { Silica Content in } \\
\text { Fuel Ash }\end{array}$ & & Fuel Pre-Treatment & Combustion Process & Scale & Main Findings & Reference \\
\hline $\begin{array}{l}\text { Material: RH } \\
\text { Source: Niigata, Japan. } \\
\text { Silica content of the fuel } \\
\text { ash: N.R. }\end{array}$ & (1) & $\begin{array}{l}20 \mathrm{~g} \text { of RH was immersed in } 500 \mathrm{~mL} \text { of sulfuric acid } \\
\text { solution for } 15 \mathrm{~min} \text { with acid concentration of } 1-5 \mathrm{wt} \\
\% \text {, and it was kept at } 444^{\circ} \mathrm{C} \text { during the leaching. } \\
\text { Water rinsing was carried out to remove acid from the } \\
\text { sample, then it was dried at } 100^{\circ} \mathrm{C} \text { for } 1 \mathrm{~h} \text { in a } \\
\text { muffle furnace. }\end{array}$ & $\begin{array}{l}\text { As-received RH and LRH } \\
\text { were burned in air at } 600 \text { and } \\
1000{ }^{\circ} \mathrm{C} \text {. } \\
\text { Atmosphere: air }\end{array}$ & TG-DTA & $\begin{array}{l}\text { Leaching RH with only } 1 \mathrm{wt} \% \text { of sulfuric acid solution reduced calcium, } \\
\text { potassium and sodium oxide impurities from chemical composition of } \\
\text { LRHA drastically. Consequently, not only the silica purity improved, but } \\
\text { also ash remained amorphous up to } 1000{ }^{\circ} \mathrm{C} \text {, whereas untreated original } \\
\text { raw RH transformed into crystalline species at temperatures above } 854^{\circ} \mathrm{C} \text {. }\end{array}$ & $\begin{array}{l}\text { Umeda et al., } \\
2007 \text { [200] }\end{array}$ \\
\hline $\begin{array}{l}\text { Material: RH } \\
\text { Source: Andhra } \\
\text { Pradesh State, India. } \\
\text { Silica content of the fuel } \\
\text { ash: N.R. }\end{array}$ & $\begin{array}{l}\text { (2) } \\
\text { (3) }\end{array}$ & $\begin{array}{l}\text { RH was washed with water to remove soluble } \\
\text { impurities, and then it was dried in a muffle furnace at } \\
\text { around } 110^{\circ} \mathrm{C} \text { for } 6-8 \mathrm{~h} \text {. } \\
\text { Around } 50 \mathrm{~g} \text { of each } \mathrm{RH} \text { was added to } 500 \mathrm{~mL} \text { of } 0.1 \mathrm{~N} \\
\mathrm{HCl} \text { acid and boil for } 1 \mathrm{~h} \text { under stirring condition. } \\
\text { Acid was decanted and LRH was washed with } \\
\text { distilled water to reach to the neutral condition at } \\
110^{\circ} \mathrm{C} \text {. }\end{array}$ & $\begin{array}{l}\text { LRH was heated up from } 300 \\
\text { to } 1000^{\circ} \mathrm{C} \text { at an interval of } \\
100^{\circ} \mathrm{C} \text { at different heating } \\
\text { rates of } 1,2,3,5,7 \text { or } 10 \\
\text { K/min and RTs of } 2,4 \text { or } 6 \mathrm{~h} \text {. } \\
\text { Atmosphere: N.R. }\end{array}$ & $\begin{array}{l}\text { Muffle } \\
\text { furnace }\end{array}$ & $\begin{array}{l}\text { Acid leaching followed by combustion at } 700^{\circ} \mathrm{C} \text { for } 2 \mathrm{~h} \text { increased silica } \\
\text { purity from } 89.5 \mathrm{wt} \% \text { in ash from untreated RH to } 97.8 \mathrm{wt} \% \text { in the ash from } \\
\text { LRH sample. Loss of ignition (LOI) test showed that in RHA obtained from } \\
\text { untreated RH, in spite of the presence of some black particles compare to the } \\
\text { ash from LRH, the value of LOI is almost the same with LRHA. It was } \\
\text { concluded that the black particles contributes to fix carbon in RHA. It was } \\
\text { shown that ash obtained from LRH switch from amorphous to crystalline } \\
\text { form at higher temperatures compared to the RHA produced from } \\
\text { untreated RH. } \\
\text { Increasing the heating rate improved surface area and pore volume and } \\
\text { decreased the brightness of the ash samples. It is because of higher carbon } \\
\text { content in RHAs obtained at higher heating rates. }\end{array}$ & $\begin{array}{l}\text { Chandrasekhar et al., } \\
2006 \text { [54] }\end{array}$ \\
\hline $\begin{array}{l}\text { Material: RH } \\
\text { Source: Kerala state } \\
\text { (KRH) and Andhra } \\
\text { Pradesh state (APRH), } \\
\text { India. } \\
\text { Silica content of the fuel } \\
\text { ash: N.R. }\end{array}$ & $\begin{array}{l}\text { (2) } \\
\text { (3) }\end{array}$ & $\begin{array}{l}\text { Around } 50 \mathrm{~g} \text { of each } \mathrm{RH} \text { was added to } 500 \mathrm{~mL} \text { of acetic, } \\
\text { oxalic, hydrochloric and nitric acids of different } \\
\text { concentrations for } 90 \text { min under stirring condition. } \\
\text { Sample was cooled and kept intact for around } 20 \mathrm{~h} \text {, } \\
\text { and then supernatant liquid was decanted. } \\
\text { Sample was washed with distilled water until } \mathrm{pH} \\
\text { equal to neutral, and then it was dried at } 110^{\circ} \mathrm{C} \text {. }\end{array}$ & $\begin{array}{l}\text { LRH, WRH, as received RH } \\
\text { samples were burned out at } \\
5 \mathrm{~K} / \mathrm{min} \text { to } 700{ }^{\circ} \mathrm{C} \text { with RT } \\
\text { of } 2 \mathrm{~h} \text {. } \\
\text { Atmosphere: N.R. }\end{array}$ & $\begin{array}{l}\text { Muffle } \\
\text { furnace }\end{array}$ & $\begin{array}{l}\text { Irrespective of CT and RT, black particles appeared in the ash obtained from } \\
\text { APRH. In spite of visible black particles in ashes obtained from APRH } \\
\text { source, LOI had around the same value all resulting ashes from two } \\
\text { different sources, which was in the range of } 1.8-4.6 \mathrm{wt} \% \text {. Therefore, it } \\
\text { indicates that there is no direct connection between black particles in the ash } \\
\text { and the carbon content obtained by LOI. } \\
\text { Further pre-treatment using different acids improved the silica purity, and } \\
\text { the maximum reported value was } 97.8 \mathrm{wt} \% \text {. } \\
\text { Nitrogen sorption analysis showed that RHA produced from } \mathrm{RH} \text { with lower } \\
\text { potassium content (KRH) had much higher SSA (approx. } 150 \mathrm{~m}^{2} / \mathrm{g} \text { ), while } \\
\text { in the sample with higher potassium content (APRH), this value was less } \\
\text { than } 10 \mathrm{~m}^{2} / \mathrm{g} \text { for the same combustion conditions. Pore volume behaves in } \\
\text { the same manner, and it was higher in the ash of KRH compared to the ash } \\
\text { of APRH. Furthermore, acid leaching improved both SSA and pore volume } \\
\text { in both samples. }\end{array}$ & $\begin{array}{l}\text { Chandrasekhar et al., } \\
2005 \text { [53] }\end{array}$ \\
\hline
\end{tabular}


Table 5. Cont.

\begin{tabular}{|c|c|c|c|c|c|c|}
\hline $\begin{array}{l}\text { Input Material, Source, } \\
\text { Silica Content in } \\
\text { Fuel Ash }\end{array}$ & & Fuel Pre-Treatment & Combustion Process & Scale & Main Findings & Reference \\
\hline $\begin{array}{l}\text { Material: RH } \\
\text { Source: N.R. } \\
\text { Silica content of the fuel } \\
\text { ash: N.R. }\end{array}$ & $\begin{array}{l}\text { (1) } \\
\text { (2) } \\
\text { (3) }\end{array}$ & $\begin{array}{l}\text { RH was washed with water. } \\
\text { WRH was leached with } \mathrm{HCl} \text { acid under stirring } \\
\text { condition at } 100^{\circ} \mathrm{C} \text { for } 1 \mathrm{~h} \text {, and then it was filtered and } \\
\text { washed with distilled water until neutralizing the acid. } \\
\text { LRH was dried at } 100^{\circ} \mathrm{C} \text { for } 24 \mathrm{~h} \text {, and then it was } \\
\text { pulverized to reach } 323 \text { mesh sizes for grains. }\end{array}$ & $\begin{array}{l}\text { LRH was heated up from } \\
\text { room temperature to } 727^{\circ} \mathrm{C} \\
\text { at heating rates of } 5,10,15, \\
\text { and } 20 \mathrm{~K} / \mathrm{min} \text {. } \\
\text { Atmosphere: air }\end{array}$ & $\begin{array}{l}\text { Thermogravi- } \\
\text { metric } \\
\text { analysis } \\
\text { (TG-DTG) in } \\
\text { a form of } \\
\text { tube reactor }\end{array}$ & $\begin{array}{l}\text { The maximum silica purity, SSA and total pore volume in LRHA reached to } \\
99.7 \mathrm{wt} \%, 235 \mathrm{~m}^{2} / \mathrm{g} \text { and } 0.32 \mathrm{~cm}^{3} / \mathrm{g} \text { for combustion at lower heating rate. } \\
\text { All LRHA obtained from different heating rates were completely } \\
\text { amorphous. }\end{array}$ & Liou, 2004 [191] \\
\hline $\begin{array}{l}\text { Material: RH } \\
\text { Source: Trakya Region, } \\
\text { Turkey. } \\
\text { Silica content of the fuel } \\
\text { ash: N.R. }\end{array}$ & $\begin{array}{l}\text { (1) } \\
\text { (2) } \\
\text { (3) }\end{array}$ & $\begin{array}{l}\text { RH was washed with water, and then it was dried at } \\
\text { around } 110^{\circ} \mathrm{C} \text { overnight. } \\
\text { WRH was leached with } 3 \%(v / v) \text { hydrochloric acid } \\
\text { and } 10 \%(v / v) \text { sulfuric acid at a ratio of } 50 \mathrm{~g} \text { WRH/l. } \\
\text { LRH was washed with distilled water following by } \\
\text { drying at } 110^{\circ} \mathrm{C} \text {. }\end{array}$ & $\begin{array}{l}20 \mathrm{~g} \text { of } \mathrm{RH}, \mathrm{WRH} \text { and } \mathrm{LRH} \\
\text { was incinerated at } 600{ }^{\circ} \mathrm{C} \text { in } \\
\text { four different ways: } \\
\text { (1) combustion for } 4 \mathrm{~h} \text { in } \\
\text { static air in muffle furnace; } \\
\text { (2) incineration in tubular } \\
\text { reactor under argon } \\
(1.5 \mathrm{~L} / \mathrm{min} \text {, for } 3 \mathrm{~h} \text { ) and then } \\
\text { supplying oxygen }(1.0 \mathrm{~L} / \mathrm{min} \\
\text { for } 1 \mathrm{~h} \text { ); (3) combustion in } \\
\text { tubular reactor under air flow } \\
(3 \mathrm{~L} / \mathrm{min} \text {, for } 3 \mathrm{~h} \text { ) and; } \\
(4) \text { combustion in tubular } \\
\text { reactor under oxygen flow } \\
(1.0 \mathrm{~L} / \text { min, for } 2 \mathrm{~h}) \text {. } \\
\text { Atmosphere: air and oxygen. }\end{array}$ & $\begin{array}{l}\text { Muffle } \\
\text { furnace \& a } \\
\text { tubular } \\
\text { reactor } \\
\text { placed } \\
\text { horizontal } \\
\text { inside the } \\
\text { muffle oven }\end{array}$ & $\begin{array}{l}\text { Incineration of untreated RH under oxygen atmosphere produced } \\
\text { amorphous RHA with silica purity of } 98.3 \mathrm{wt} \% \text {. However, silica purity in } \\
\text { the static air condition was } 91.5 \mathrm{wt} \% \text {. } \\
\text { Result of RH, WRH, and LRH combustion under static air showed that silica } \\
\text { purity increased from } 91.5 \mathrm{wt} \% \text { in the untreated sample to } 95.5 \mathrm{wt} \% \text { and } \\
99.2 \mathrm{wt} \% \text { in distilled water washed and HCl-leached samples, respectively. } \\
\text { Furthermore, maximum purity obtained from sulfuric acid pre-treatment } \\
(99.6 \mathrm{wt} \%) \text {. }\end{array}$ & $\begin{array}{c}\text { Yalçin and } \\
\text { Secinç, 2001 } \\
\text { [181] }\end{array}$ \\
\hline
\end{tabular}

${ }^{1}$ SSA: specific surface area; ${ }^{2} \mathrm{CT}$ : conversion temperature; ${ }^{3} \mathrm{RT}$ : residence time. 
Table 6. Combination of ash post-treatment with fuel pre-treatment and combustion to obtain pure biogenic silica from RH and RS.

\begin{tabular}{|c|c|c|c|c|c|c|c|}
\hline $\begin{array}{l}\text { Input Material, Source, } \\
\text { Silica Content in Fuel Ash }\end{array}$ & & Pre-Treatment Process & Combustion Process & Scale & Post-Treatment Process & Main Findings & Reference \\
\hline $\begin{array}{l}\text { Material: RH } \\
\text { Source: Cambodia and Italy. } \\
\text { Silica content of the fuel ash: } \\
\text { N.R. }\end{array}$ & (1) & $\begin{array}{l}\text { RHs were sieved, washed with tap } \\
\text { water at } 50^{\circ} \mathrm{C} \text { for } 2 \mathrm{~h} \text { and dried. In } \\
\text { some cases, RH was leached with } 1 \\
\text { wt } \% \text { citric acid at } 50^{\circ} \mathrm{C} \text { for } 2 \\
\mathrm{~h} \text { instead. Note: Prior to the bench } \\
\text { scale experiments, different } \\
\text { pre-treatment conditions including } \\
\text { time, temperature, concentration } \\
\text { and type of acid were investigated } \\
\text { in lab-scale experiments using a } \\
\text { muffle oven. }\end{array}$ & $\begin{array}{l}\text { Combustion was } \\
\text { carried out using } \\
\text { OKOTHERM } \\
\text { boilers, and RH was } \\
\text { continuously } \\
\text { supplied into the } \\
\text { boilers. }\end{array}$ & $\begin{array}{l}\text { Muffle oven for lab } \\
\text { scale studies and } \\
\text { post-treatment and } \\
\text { OKOTHERM }^{\circledR} \\
\text { boilers with power up } \\
\text { to } 120 \mathrm{~kW} \text { for } \\
\text { bench-scale studies. }\end{array}$ & $\begin{array}{l}\text { (1) RHA was leached with } \\
0.5-2 \text { wt } \% \text { of citric } \\
\text { acid or hydrochloric } \\
\text { acid at } 50^{\circ} \mathrm{C} \text { for } 2 \mathrm{~h} \text {. } \\
\text { (2) Acid-leached RHA } \\
\text { was heated up in air at } \\
650^{\circ} \mathrm{C} \text { in a } \\
\text { muffle oven. }\end{array}$ & $\begin{array}{l}\text { This research is the first known attempt to consider both } \\
\text { energy and material applications of agricultural residues in a } \\
\text { real combustion unit. } \\
\text { Some optimization for huge ash loading was done by } \\
\text { modifying the conveying screw and using additional } \\
\text { mechanical equipment to mobilize and transport the } \\
\text { voluminous ash inside the boiler. As a result, the operation } \\
\text { time was prolonged with no limit in fuel handling and ash } \\
\text { discharged. } \\
\text { Considering the principles of green chemistry by using less } \\
\text { chemical resources, the cost of the process as well as the } \\
\text { quality of the obtained biogenic silica, water washing and } 2 \mathrm{wt} \\
\% \text { citric acid leaching at } 50^{\circ} \mathrm{C} \text { for } 2 \mathrm{~h} \text { were selected, } \\
\text { respectively, as the pre-treatment and post-treatment. The } \\
\text { final product had an amorphous internal structure with BET } \\
\mathrm{SSA} \mathrm{A}^{1}, \mathrm{specific} \mathrm{mesoporous}^{2} \text { volume and silica purity of } \\
185 \mathrm{~m}^{2} / \mathrm{g}, 0.25 \mathrm{~cm}^{3} / \mathrm{g} \text {, and }>98 \mathrm{wt} \% \text {, respectively. }\end{array}$ & $\begin{array}{l}\text { Schliermann et al., } \\
2018 \text { [73] }\end{array}$ \\
\hline $\begin{array}{l}\text { Material: RHA was } \\
\text { supplied by a local industry } \\
\text { (Fumacense, Morro da } \\
\text { Fumaça, SC, Brazil). } \\
\text { Silica content: } 72.1 \mathrm{wt} \%\end{array}$ & - & & N.R. & $\begin{array}{l}\text { Electric oven with } \\
\text { crucible of } 24.5 \mathrm{~cm} \\
\text { diameter. }\end{array}$ & $\begin{array}{l}\text { RHA was heated from room } \\
\text { temperature to } 400,500,600, \\
\text { or } 700^{\circ} \mathrm{C} \text { for } 3-6 \mathrm{~h} \text { with } \\
\text { heating rate of } 10 \mathrm{~K} / \mathrm{min} \text {. }\end{array}$ & $\begin{array}{l}\text { Simply heating the RHA to } 700^{\circ} \mathrm{C} \text { for } 6 \mathrm{~h} \text { improved silica } \\
\text { purity of the ash from } 72.1 \text { to } 95 \mathrm{wt} \% \text {, and RHA remined in } \\
\text { amorphous form. However, SSA was changed from } 177 \mathrm{~m}^{2} / \mathrm{g} \\
\text { in the as-received RHA to } 54 \mathrm{~m}^{2} / \mathrm{g} \text { in reheated RHA sample. }\end{array}$ & $\begin{array}{l}\text { Della et al., } \\
2002 \text { [64] }\end{array}$ \\
\hline $\begin{array}{l}\text { Material: RH } \\
\text { Source: Trakya Region, } \\
\text { Turkey. } \\
\text { Silica content of the fuel ash: } \\
\text { N.R. }\end{array}$ & (1) & $\begin{array}{l}\text { RH was washed with water, and } \\
\text { then it was dried at around } \\
110^{\circ} \mathrm{C} \text { overnight. } \\
\text { WRH was leached with } 3 \%(v / v) \\
\text { hydrochloric acid at a ratio of } 50 \mathrm{~g} \\
\text { WRH/l for } 2 \mathrm{~h} \text {. } \\
\text { LRH was washed with distilled } \\
\text { water following by drying at } \\
110^{\circ} \mathrm{C} \text {. }\end{array}$ & $\begin{array}{l}20 \mathrm{~g} \text { of } \mathrm{RH}, \mathrm{WRH}, \\
\mathrm{LRH} \text { was incinerated } \\
\text { at } 600^{\circ} \mathrm{C} \text {. } \\
\text { Atmosphere: air }\end{array}$ & Muffle furnace & $\begin{array}{l}\text { RHA produced from } \\
\text { untreated and acid leached } \\
\text { RH was leached with } 3 \% \\
(v / v) \mathrm{HCl} \text { a a ratio of } 50 \mathrm{~g} \\
\mathrm{WRH} / \mathrm{l} \text { for } 2 \mathrm{~h} \text {. }\end{array}$ & $\begin{array}{l}\text { The order of the silica purity was acid pre- and post-treated } \\
\text { sample }(99.7 \mathrm{wt} \%)>\text { acid pre-treated sample }(99.2 \mathrm{wt} \%)> \\
\text { water pre-treated sample }(95.5 \mathrm{wt} \%)>\text { acid post-treated } \\
\text { sample }(95.1 \mathrm{wt} \%)>\text { untreated sample }(91.5 \mathrm{wt} \%) \text {. } \\
\text { SSA results revealed that the order of the SSA was untreated } \\
\text { sample }\left(63 \mathrm{~m}^{2} / \mathrm{g} \text { ), water washed sample }\left(194 \mathrm{~m}^{2} / \mathrm{g}\right) \text {, acid pre- }\right. \\
\text { and post-treated sample }\left(244 \mathrm{~m}^{2} / \mathrm{g}\right) \text {, and acid pre-treated } \\
\text { sample }\left(321 \mathrm{~m}^{2} / \mathrm{g}\right) \text {, respectively. }\end{array}$ & $\begin{array}{c}\text { Yalçin and } \\
\text { Secinç, 2001 } \\
\text { [181] }\end{array}$ \\
\hline
\end{tabular}

${ }^{1}$ SSA: specific surface area. 
Schliermann et al. $[73,202]$ used pre-treated RH for combustion in a commercially available biomass boiler and applied post-treatment of the ash to improve the quality of biogenic silica. Thus, heat production was successfully combined with generation of biogenic silica considering also process cost and the principles of green chemistry. Amorphous biogenic silica was produced with purities exceeding $98 \mathrm{wt} \%$ and with satisfying SSA of approx. $185 \mathrm{~m}^{2} / \mathrm{g}$ as well as mesopore volume of $0.25 \mathrm{~cm}^{3} / \mathrm{g}$. Furthermore, Schliermann et al. [73,202] improved the operating conditions of the combustion unit to reach to a continuous fuel supply with very low gaseous and particulate matter emissions.

\section{Summary and Conclusions}

In this comprehensive review, combinations of fuel pre- and ash post-treatment strategies with combustion of rice husk (RH) and rice straw (RS) have been discussed. With respect to the review objective, we conclude that:

(1) By studying the ash melting tendency of original and treated RH and RS, it was shown that there is a gap in knowledge, and further investigation is required in this field.

(2) Fuel pre-treatment has a significant impact on controlling ash melting issue in RH and RS, and it seems that at least water washing prior to combustion is essential in RS to avoid slag formation.

(3) Increasing combustion temperature (CT) and residence time (RT) improves the purity of the biogenic silica with respect to the carbon content. At the same time, specific surface area (SSA) and pore volume of the biogenic silica decrease while the risk of crystallization is increased. The alternative strategy to improve all quality characteristics of rice husk ash (RHA) and rice straw ash (RSA) is using fuel pre-treatment prior to the combustion. Crystallization tendency of RHA possibly correlates with the alkali metal content, which facilitates formation of cristobalite. Crystallization temperature is around $600-900{ }^{\circ} \mathrm{C}$ in untreated RH and RS depending on the elemental composition, whereas pre-treated RH and RS remain amorphous up to higher temperatures of about $1000{ }^{\circ} \mathrm{C}$.

(4) In RHA from untreated RH, the maximum silica purity, SSA and pore volume are around $97.2 \mathrm{wt} \%, 220 \mathrm{~m}^{2} / \mathrm{g}$ and $0.26 \mathrm{~cm}^{3} / \mathrm{g}$, respectively. However, these values can be improved to around $99.8 \mathrm{wt} \%, 353 \mathrm{~m}^{2} / \mathrm{g}$ and $0.52 \mathrm{~cm}^{3} / \mathrm{g}$ using fuel pre-treatment strategies prior to the combustion. Further improvement of silica purity is possible by a combination of fuel pre-treatment, combustion and ash post-treatment strategies.

(5) Although high quality biogenic silica can be produced from RH and RS, most studies were performed in lab-scale muffle furnaces and investigations at a bench scale are scarce.

(6) Economically feasible production of biogenic silica from $\mathrm{RH}$ was demonstrated at a bench scale though with silica purity limited to $98 \mathrm{wt} \%$. For higher silica purities, a harsh pre- and post-treatment environment may be required, which could increase the technical efforts and thus the overall process costs.

(7) Finally, it was shown that a preliminary practical study has been done to scale the production procedure up to a bench scale with the aim of developing an environmentally friendly and economically feasible process with coupled energetic and material utilization of RH. However, further investigations are required to understand the behavior of RH and RS in combustion. Moreover, there is no report in literature to predict the quality of biogenic silica as well as the ash melting tendency and gaseous emissions using thermodynamic calculations. By using thermodynamic calculations, the effect of chemical composition of input material can also be evaluated in order to transfer to other biomasses since there are limited experimental data available in literature. No information is available in literature on computational fluid dynamic (CFD) simulation of the combustion process of biomass to simulate their conversion mechanism to biogenic silica inside the boiler. If a CFD simulation is used, thermal efficiency of the combustion unit can also be evaluated and optimized. In addition, such a simulation will be valuable to 
calculate the exact $\mathrm{CT}$ and RT of each singular biomass particle during the real operational condition of the combustion unit. In the literature, fundamental lab-scale studies are usually carried out in static airflow. However, the effect of dynamic airflow and air to fuel ratio on the quality of resulting ash have not being studied in the literature. Although many people have measured the biogenic silica purity and pore structure of the ash obtained from RH and $\mathrm{RS}$, there is no information about the accuracy and repeatability of the measurements in the literature, and it seems this gap should be considered in future investigations. Sustainability, economic, and energetic analysis are essential once a commercial plant becomes available to produce biogenic silica from $\mathrm{RH}$ and $\mathrm{RH}$ in a process including the combination of pre- and post-treatment strategies with combustion.

Author Contributions: H.B.D. wrote the manuscript and revised it, T.Z., I.H., D.E., T.S., V.L. and M.B. contributed to review and edit the manuscript. The main review was performed by T.Z., I.H., D.E. and T.S.

Acknowledgments: The work was supported by funds of the German Federal Ministry of Food and Agriculture (BMEL) based on a decision of the Parliament of the Federal Republic of Germany via the Federal Office of Agriculture and Food (BLE) under grant agreement number 2816DOKI03 and under the innovation support program. Authors would like to express their sincere thanks to Annett Pollex for her proofreading and the comments.

Conflicts of Interest: The authors declare no conflict of interest regarding the publication of this review.

$\begin{array}{ll}\text { Abbreviations } \\ \text { The following abbreviations are used in the manuscript: } \\ \text { DT } & \text { initial deformation ash fusion temperature } \\ \text { db } & \text { dry basis } \\ \text { LOI } & \text { loss of ignition } \\ \text { LRH } & \text { acid-leached rice husk } \\ \text { LRHA } & \text { acid-leached rice husk ash } \\ \text { LRS } & \text { acid-leached rice straw } \\ \text { LRSA } & \text { acid-leached rice straw ash } \\ \text { PRH } & \text { pyrolized rice husk } \\ \text { RH } & \text { as received rice husk } \\ \text { RHA } & \text { rice husk ash } \\ \text { RS } & \text { as received rice straw } \\ \text { RSA } & \text { rice straw ash } \\ \text { WRH } & \text { water-washed rice husk } \\ \text { WRHA } & \text { water-washed rice husk ash } \\ \text { WRS } & \text { water-washed rice straw } \\ \text { WRSA } & \text { water-washed rice straw ash } \\ \lambda & \text { excess air ratio }\end{array}$

\section{References}

1. International Energy Agency. World Energy Outlook 2018; ISBN 978-92-64-06452-2. Available online: https: //webstore.iea.org/world-energy-outlook-2018 (accessed on 4 March 2019).

2. McKendry, P. Energy Production from Biomass (Part 1): Overview of Biomass. Bioresour. Technol. 2002, 83, 37-46. [CrossRef]

3. Food and Agriculture Organization of the United Nations. Countries by Commodity (Rice, Paddy) [Statistical Database], 2008. Available online: http:/ / faostat.fao.org/site/339/default.aspx (accessed on 4 March 2019).

4. Food and Agriculture Organization of the United Nations (FAO). Rice Market Monitor: April 2018. Available online: http:/ / www.fao.org/3/19243EN/i9243en.pdf (accessed on 13 November 2018).

5. Food and Agriculture Organization of the United Nations (FAO). Rice Market Monitor: December 2017. Available online: http:/ / www.fao.org/3/I8317EN/I8317EN.pdf (accessed on 13 November 2018). 
6. Food and Agriculture Organization of the United Nations (FAO). Rice Market Monitor: December 2006. Available online: http://www.fao.org/tempref/docrep/fao/009/ah614e/ah614e00.pdf (accessed on 13 November 2018).

7. Food and Agriculture Organization of the United Nations (FAO). Rice Market Monitor: December 2007. Available online: http://www.fao.org/tempref/docrep/fao/010/ai458e/ai458e00.pdf (accessed on 13 November 2018).

8. Food and Agriculture Organization of the United Nations (FAO). Rice market Monitor: July 2008. Available online: http://www.fao.org/tempref/docrep/fao/011/ak001e/ak001e00.pdf (accessed on 13 November 2018).

9. Food and Agriculture Organization of the United Nations (FAO). Rice Market Monitor: December 2009. Available online: http:/ / www.fao.org/docrep/012/al004e/al004e00.pdf (accessed on 13 November 2018).

10. Food and Agriculture Organization of the United Nations (FAO). Rice Market Monitor: November 2010. Available online: http:/ / www.fao.org/docrep/013/am016e/am016e00.pdf (accessed on 13 November 2018).

11. Food and Agriculture Organization of the United Nations (FAO). Rice Market Monitor: November 2011. Available online: http:/ / www.fao.org/docrep/014/am945e/am945e00.pdf (accessed on 13 November 2018).

12. Food and Agriculture Organization of the United Nations (FAO). Rice Market Monitor: November 2012. Available online: http:/ / www.fao.org/docrep/017/ap772e/ap772e.pdf (accessed on 13 November 2018).

13. Food and Agriculture Organization of the United Nations (FAO). Rice Market Monitor: November 2013. Available online: http:/ / www.fao.org/docrep/019/as201e/as201e.pdf (accessed on 13 November 2018).

14. Food and Agriculture Organization of the United Nations (FAO). Rice Market Monitor: December 2014. Available online: http:/ / www.fao.org/3/a-i4294e.pdf (accessed on 13 November 2018).

15. Food and Agriculture Organization of the United Nations (FAO). Rice Market Monitor: December 2015. Available online: http://www.fao.org/fileadmin/templates/est/COMM_MARKETS_MONITORING/ Rice/Images/RMM/RMM_DEC15_H.pdf (accessed on 13 November 2018).

16. Food and Agriculture Organization of the United Nations (FAO). Rice Market Monitor: December 2016. Available online: http:/ /www.fao.org/fileadmin/templates/est/COMM_MARKETS_MONITORING/ Rice/Images/RMM/RMM-Dec16_H.pdf (accessed on 13 November 2018).

17. Chen, H.; Wang, W.; Martin, J.C.; Oliphant, A.J.; Doerr, P.A.; Xu, J.F.; DeBorn, K.M.; Chen, C.; Sun, L. Extraction of Lignocellulose and Synthesis of Porous Silica Nanoparticles from Rice Husks: A Comprehensive Utilization of Rice Husk Biomass. ACS Sustain. Chem. Eng. 2013, 1, 254-259. [CrossRef]

18. Kadam, K.L.; Forrest, L.H.; Jacobson, W.A. Rice straw as a lignocellulosic resource: Collection, processing, transportation, and environmental aspects. Biomass Bioenergy 2000, 18, 369-389. [CrossRef]

19. Blissett, R.; Sommerville, R.; Rowson, N.; Jones, J.; Laughlin, B. Valorisation of rice husks using a TORBED ${ }^{\circledR}$ combustion process. Fuel Process. Technol. 2017, 159, 247-255. [CrossRef]

20. Chen, X.-G.; Lv, S.-S.; Zhang, P.-P.; Zhang, L.; Ye, Y. Thermal destruction of rice hull in air and nitrogen. J. Therm. Anal. Calorim. 2011, 104, 1055-1062. [CrossRef]

21. Food and Agriculture Organization of the United Nations (FAO). Sustainable Rice Production for Food Security 2002 [Statistical Database]. Available online: http:/ /www.fao.org/docrep/006/Y4751E/y4751e00. htm (accessed on 13 November 2018).

22. Jain, A.; Rajeswara Rao, T.; Sambi, S.S.; Grover, P.D. Energy and chemicals from rice husk. Biomass Bioenergy 1994, 7, 285-289. [CrossRef]

23. Fang, M.; Yang, L.; Chen, G.; Shi, Z.; Luo, Z.; Cen, K. Experimental study on rice husk combustion in a circulating fluidized bed. Fuel Process. Technol. 2004, 85, 1273-1282. [CrossRef]

24. Lim, J.S.; Abdul Manan, Z.; Wan Alwi, S.R.; Hashim, H. A review on utilisation of biomass from rice industry as a source of renewable energy. Renew. Sustain. Energy Rev. 2012, 16, 3084-3094. [CrossRef]

25. Van, V.-T.-A.; Rößler, C.; Bui, D.-D.; Ludwig, H.-M. Pozzolanic reactivity of mesoporous amorphous rice husk ash in portlandite solution. Constr. Build. Mater. 2014, 59, 111-119. [CrossRef]

26. Zain, M.F.M.; Islam, M.N.; Mahmud, F.; Jamil, M. Production of rice husk ash for use in concrete as a supplementary cementitious material. Constr. Build. Mater. 2011, 25, 798-805. [CrossRef]

27. Rêgo, J.H.S.; Nepomuceno, A.A.; Figueiredo, E.P.; Hasparyk, N.P. Microstructure of cement pastes with residual rice husk ash of low amorphous silica content. Constr. Build. Mater. 2015, 80, 56-68.

28. Foo, K.Y.; Hameed, B.H. Utilization of rice husk ash as novel adsorbent: A judicious recycling of the colloidal agricultural waste. Adv. Colloid Interface Sci. 2009, 152, 39-47. [CrossRef] [PubMed] 
29. Srivastava, V.C.; Mall, I.D.; Mishra, I.M. Competitive adsorption of cadmium(II) and nickel(II) metal ions from aqueous solution onto rice husk ash. Chem. Eng. Process. Process Intensif. 2009, 48, 370-379. [CrossRef]

30. Arabahmadi, V.; Ghorbani, M. Pb (II) removal from water using surface-modified polythiophene-coated rice husk ash nanocomposite. Inorg. Nano-Met. Chem. 2017, 47, 1614-1624. [CrossRef]

31. Ghorbani, M.; Eisazadeh, H. Fixed bed column study for $\mathrm{Zn}, \mathrm{Cu}, \mathrm{Fe}$ and $\mathrm{Mn}$ removal from wastewater using nanometer size polypyrrole coated on rice husk ash. Synth. Met. 2012, 162, 1429-1433. [CrossRef]

32. Ghorbani, M.; Eisazadeh, H. Removal of COD, color, anions and heavy metals from cotton textile wastewater by using polyaniline and polypyrrole nanocomposites coated on rice husk ash. Compos. Part B Eng. 2013, 45, 1-7. [CrossRef]

33. Ghorbani, M.; Lashkenari, M.S.; Eisazadeh, H. Application of polyaniline nanocomposite coated on rice husk ash for removal of $\mathrm{Hg}$ (II) from aqueous media. Synth. Met. 2011, 161, 1430-1433. [CrossRef]

34. Liu, D.; Seeburg, D.; Kreft, S.; Bindig, R.; Hartmann, I.; Schneider, D.; Enke, D.; Wohlrab, S. Rice Husk Derived Porous Silica as Support for Pd and CeO2 for Low Temperature Catalytic Methane Combustion. Catalysts 2019, 9, 26. [CrossRef]

35. Feng, Q.; Lin, Q.; Gong, F.; Sugita, S.; Shoya, M. Adsorption of lead and mercury by rice husk ash. J. Colloid Interface Sci. 2004, 278, 1-8. [CrossRef]

36. Naiya, T.K.; Bhattacharya, A.K.; Mandal, S.; Das, S.K. The sorption of lead(II) ions on rice husk ash. J. Hazard. Mater. 2009, 163, 1254-1264. [CrossRef] [PubMed]

37. Tiwari, D.P.; Singh, D.K.; Saksena, D.N. Hg(II) Adsorption from Aqueous Solutions Using Rice-Husk Ash. J. Environ. Eng. 1995, 121, 479-481. [CrossRef]

38. Srivastava, V.C.; Mall, I.D.; Mishra, I.M. Removal of cadmium(II) and zinc(II) metal ions from binary aqueous solution by rice husk ash. Colloids Surf. A Physicochem. Eng. Asp. 2008, 312, 172-184. [CrossRef]

39. Chareonpanich, M.; Namto, T.; Kongkachuichay, P.; Limtrakul, J. Synthesis of ZSM-5 zeolite from lignite fly ash and rice husk ash. Fuel Process. Technol. 2004, 85, 1623-1634. [CrossRef]

40. Vempati, R.K.; Borade, R.; Hegde, R.S.; Komarneni, S. Template free ZSM-5 from siliceous rice hull ash with varying C contents. Microporous Mesoporous Mater. 2006, 93, 134-140. [CrossRef]

41. Jang, H.T.; Park, Y.; Ko, Y.S.; Lee, J.Y.; Margandan, B. Highly siliceous MCM-48 from rice husk ash for $\mathrm{CO}_{2}$ adsorption. Int. J. Greenh. Gas Control 2009, 3, 545-549. [CrossRef]

42. Ahmad-Alyosef, H.; Gert Kloess, T.M.; Einicke, W.-D.; Gläser, R.; Enke, D. Biogenic Silica from Rice Husk Ash-Sustainable Sources for the Synthesis of Value Added Silica; A Publication of AIDIC The Italian Association of Chemical Engineering; The Italian Association of Chemical Engineering: Milan, Italy, 2014.

43. Alyosef, H.A.; Roggendorf, H.; Schneider, D.; Inayat, A.; Welscher, J.; Schwieger, W.; Münster, T.; Kloess, G.; Ibrahim, S.; Enke, D. Comparative Study between Direct and Pseudomorphic Transformation of Rice Husk Ash into MFI-Type Zeolite. Molecules 2017, 23. [CrossRef]

44. Ng, E.-P.; Awala, H.; Tan, K.-H.; Adam, F.; Retoux, R.; Mintova, S. EMT-type zeolite nanocrystals synthesized from rice husk. Microporous Mesoporous Mater. 2015, 204, 204-209. [CrossRef]

45. Mohamed, R.M.; Mkhalid, I.A.; Barakat, M.A. Rice husk ash as a renewable source for the production of zeolite NaY and its characterization. Arab. J. Chem. 2015, 8, 48-53. [CrossRef]

46. Jullaphan, O.; Witoon, T.; Chareonpanich, M. Synthesis of mixed-phase uniformly infiltrated SBA-3-like in SBA-15 bimodal mesoporous silica from rice husk ash. Mater. Lett. 2009, 63, 1303-1306. [CrossRef]

47. He, Q.; Shi, J. Mesoporous silica nanoparticle based nano drug delivery systems: Synthesis, controlled drug release and delivery, pharmacokinetics and biocompatibility. J. Mater. Chem. 2011, 21, 5845. [CrossRef]

48. Kwon, S.; Singh, R.K.; Perez, R.A.; Abou Neel, E.A.; Kim, H.-W.; Chrzanowski, W. Silica-based mesoporous nanoparticles for controlled drug delivery. J. Tissue Eng. 2013, 4. [CrossRef]

49. Pode, R. Potential applications of rice husk ash waste from rice husk biomass power plant. Renew. Sustain. Energy Rev. 2016, 53, 1468-1485. [CrossRef]

50. Soltani, N.; Bahrami, A.; Pech-Canul, M.I.; González, L.A. Review on the physicochemical treatments of rice husk for production of advanced materials. Chem. Eng. J. 2015, 264, 899-935. [CrossRef]

51. Shen, Y. Rice husk silica derived nanomaterials for sustainable applications. Renew. Sustain. Energy Rev. 2017, 80, 453-466. [CrossRef]

52. Yao, X.; Xu, K.; Liang, Y. Comparing the Thermo-Physical Properties of Rice Husk and Rice Straw as Feedstock for Thermochemical Conversion and Characterization of their Waste Ashes from Combustion. BioResources 2016, 11. [CrossRef] 
53. Chandrasekhar, S.; Pramada, P.N.; Praveen, L. Effect of organic acid treatment on the properties of rice husk silica. J. Mater. Sci. 2005, 40, 6535-6544. [CrossRef]

54. Chandrasekhar, S.; Pramada, P.N.; Majeed, J. Effect of calcination temperature and heating rate on the optical properties and reactivity of rice husk ash. J. Mater. Sci. 2006, 41, 7926-7933. [CrossRef]

55. Shen, Y.; Zhao, P.; Shao, Q. Porous silica and carbon derived materials from rice husk pyrolysis char. Microporous Mesoporous Mater. 2014, 188, 46-76. [CrossRef]

56. Tchakouté, H.K.; Rüscher, C.H.; Kong, S.; Ranjbar, N. Synthesis of sodium waterglass from white rice husk ash as an activator to produce metakaolin-based geopolymer cements. J. Build. Eng. 2016, 6, 252-261. [CrossRef]

57. Pfeiffer, T.; Enke, D.; Roth, R.; Roggendorf, H. Hydrothermal Dissolution of Opal in Sodium Hydroxide Lyes for the Synthesis of Water Glass. ACES 2017, 07, 76-90. [CrossRef]

58. Wang, W.; Martin, J.C.; Zhang, N.; Ma, C.; Han, A.; Sun, L. Harvesting silica nanoparticles from rice husks. J. Nanopart. Res. 2011, 13, 6981-6990. [CrossRef]

59. Yang, H.; Liu, B.; Chen, Y.; Li, B.; Chen, H. Influence of Inherent Silicon and Metals in Rice Husk on the Char Properties and Associated Silica Structure. Energy Fuels 2015, 29, 7327-7334. [CrossRef]

60. Rice, F.; Park, R.; Stayner, L.; Smith, R.; Gilbert, S.; Checkoway, H. Crystalline silica exposure and lung cancer mortality in diatomaceous earth industry workers: A quantitative risk assessment. Occupat. environ. medicine 2001, 58, 38-45. [CrossRef]

61. DHHS, Department of Health and Human Services, Centers for Disease Control and Prevention. Health Effects of Occupational Exposure to Respirable Crystalline Silica, DHHS (NIOSH) Publication No. 2002-129, 2002.

62. Bhattacharya, S.C.; Shah, N.; Alikhani, Z. Some aspects of fluidized bed combustion of paddy husk. Appl. Energy 1984, 16, 307-316. [CrossRef]

63. Bhattacharya, S.C.; Wu, W. Fluidized Bed Combustion of Rice Husk for Disposal and Energy Recovery. Energy Biomass Wastes XII 1989, 12, 591-601.

64. Della, V.P.; Kühn, I.; Hotza, D. Rice husk ash as an alternate source for active silica production. Mater. Lett. 2002, 57, 818-821. [CrossRef]

65. Nehdi, M.; Duquette, J.; El Damatty, A. Performance of rice husk ash produced using a new technology as a mineral admixture in concrete. Cem. Concr. Res. 2003, 33, 1203-1210. [CrossRef]

66. Rozainee, M.; Ngo, S.P.; Salema, A.A.; Tan, K.G. Fluidized bed combustion of rice husk to produce amorphous siliceous ash. Energy Sustain. Dev. 2008, 12, 33-42. [CrossRef]

67. Umeda, J.; Kondoh, K. High-purity amorphous silica originated in rice husks via carboxylic acid leaching process. J. Mater. Sci 2008, 43, 7084-7090. [CrossRef]

68. Martínez, J.D.; Pineda, T.; López, J.P.; Betancur, M. Assessment of the rice husk lean-combustion in a bubbling fluidized bed for the production of amorphous silica-rich ash. Energy 2011, 36, 3846-3854. [CrossRef]

69. Bie, R.-S.; Song, X.-F.; Liu, Q.-Q.; Ji, X.-Y.; Chen, P. Studies on effects of burning conditions and rice husk ash (RHA) blending amount on the mechanical behavior of cement. Cem. Concr. Compos. 2015, 55, 162-168. [CrossRef]

70. Faé Gomes, G.M.; Philipssen, C.; Bard, E.K.; Zen, L.D.; Souza, G.d. Rice husk bubbling fluidized bed combustion for amorphous silica synthesis. J. Environ. Chem. Eng. 2016, 4, 2278-2290. [CrossRef]

71. Chen, P.; Gu, W.; Fang, W.; Ji, X.; Bie, R. Removal of metal impurities in rice husk and characterization of rice husk ash under simplified acid pretreatment process. Environ. Prog. Sustain. Energy 2017, 36, 830-837. [CrossRef]

72. Schneider, D.; Wassersleben, S.; Weiß, M.; Denecke, R.; Stark, A.; Enke, D. A Generalized Procedure for the Production of High-Grade, Porous Biogenic Silica. Waste Biomass Valor 2018, 37, 667. [CrossRef]

73. Schliermann, T.; Hartmann, I.; Beidaghy Dizaji, H.; Zeng, T.; Schneider, D.; Wassersleben, S.; Enke, D.; Jobst, T.; Lange, A.; Roelofs, F.; et al. High quality biogenic silica from combined energetic and material utilization of agricultural residues. In Proceedings of the 7th International Symposium of Energy from Biomass and Waste, Venice, Italy, 15-18 October 2018; ISBN 978-8-86-265013-7.

74. Tutsek, A.; Bartha, P. Method of Producing Low-Carbon White Husk Ash. US Patent No. US4049464, 20 September 1977.

75. Chandrasekhar, S.; Satyanarayana, K.G.; Pramada, P.N.; Raghavan, P.; Gupta, T.N. Review Processing, properties and applications of reactive silica from rice husk-An overview. J. Mater. Sci. 2003, 38, 3159-3168. [CrossRef] 
76. Chuah, T.G.; Jumasiah, A.; Azni, I.; Katayon, S.; Thomas Choong, S.Y. Rice husk as a potentially low-cost biosorbent for heavy metal and dye removal: An overview. Desalination 2005, 175, 305-316. [CrossRef]

77. Adam, F.; Appaturi, J.N.; Iqbal, A. The utilization of rice husk silica as a catalyst: Review and recent progress. Catal. Today 2012, 190, 2-14. [CrossRef]

78. Malhotra, V.M. Fly Ash, Slag, Silica Fume, and Rice Husk Ash in Concrete: A Review. Concr. Int. 1993, 15, 23-28.

79. Quispe, I.; Navia, R.; Kahhat, R. Energy potential from rice husk through direct combustion and fast pyrolysis: A review. Waste Manag. 2017, 59, 200-210. [CrossRef]

80. Karim, M.R.; Zain, M.F.M.; Jamil, M. Strength of mortar and concrete as influenced by rice husk ash: A review. World Appl. Sci. J. 2012, 19, 1501-1513.

81. Chen, Y.; Zhu, Y.; Wang, Z.; Li, Y.; Wang, L.; Ding, L.; Gao, X.; Ma, Y.; Guo, Y. Application studies of activated carbon derived from rice husks produced by chemical-thermal process-A review. Adv. Colloid Interface Sci. 2011, 163, 39-52. [CrossRef] [PubMed]

82. Natarajan, E.; Nordin, A.; Rao, A.N. Overview of combustion and gasification of rice husk in fluidized bed reactors. Biomass Bioenergy 1998, 14, 533-546. [CrossRef]

83. Muthadhi, A.; Anitha, R.; Kothandaraman, S. Rice husk ash-Properties and its uses: A review. J. Inst. Eng. Civ. Eng. Divis. 2007, 88, 50-56.

84. Prasad, R.; Pandey, M. Rice Husk Ash as a Renewable Source for the Production of Value Added Silica Gel and its Application: An Overview. Bull. Chem. React. Eng. Catal. 2012, 7. [CrossRef]

85. Prasara-A, J.; Gheewala, S.H. Sustainable utilization of rice husk ash from power plants: A review. J. Clean. Prod. 2017, 167, 1020-1028. [CrossRef]

86. Sandhu, R.K.; Siddique, R. Influence of rice husk ash (RHA) on the properties of self-compacting concrete: A review. Constr. Build. Mater. 2017, 153, 751-764. [CrossRef]

87. Khan, M.N.N.; Jamil, M.; Karim, M.R.; Zain, M.F.M.; Kaish, A.B.M.A. Utilization of Rice Husk Ash for Sustainable Construction: A Review. RJASET 2015, 9, 1119-1127. [CrossRef]

88. Ahmaruzzaman, M.; Gupta, V.K. Rice Husk and Its Ash as Low-Cost Adsorbents in Water and Wastewater Treatment. Ind. Eng. Chem. Res. 2011, 50, 13589-13613. [CrossRef]

89. Sun, L.; Gong, K. Silicon-Based Materials from Rice Husks and Their Applications. Ind. Eng. Chem. Res. 2001, 40, 5861-5877. [CrossRef]

90. Shen, Y. Rice Husk Silica-Derived Nanomaterials for Battery Applications: A Literature Review. J. Agric. Food Chem. 2017, 65, 995-1004. [CrossRef] [PubMed]

91. Lee, J.H.; Kwon, J.H.; Lee, J.-W.; Lee, H.-S.; Chang, J.H.; Sang, B.-I. Preparation of high purity silica originated from rice husks by chemically removing metallic impurities. J. Ind. Eng. Chem. 2017, 50, 79-85. [CrossRef]

92. Pollex, A.; Zeng, T.; Khalsa, J.; Erler, U.; Schmersahl, R.; Schön, C.; Kuptz, D.; Lenz, V.; Nelles, M. Content of potassium and other aerosol forming elements in commercially available wood pellet batches. Fuel 2018, 232, 384-394. [CrossRef]

93. Vassilev, S.V.; Baxter, D.; Andersen, L.K.; Vassileva, C.G. An overview of the composition and application of biomass ash. Part 1. Phase-mineral and chemical composition and classification. Fuel 2013, 105, 40-76. [CrossRef]

94. Zevenhoven-Onderwater, M.; Blomquist, J.-P.; Skrifvars, B.-J.; Backman, R.; Hupa, M. The prediction of behaviour of ashes from five different solid fuels in fluidised bed combustion. Fuel 2000, 79, 1353-1361. [CrossRef]

95. Lindström, E.; Öhman, M.; Backman, R.; Boström, D. Influence of Sand Contamination on Slag Formation during Combustion of Wood Derived Fuels. Energy Fuels 2008, 22, 2216-2220. [CrossRef]

96. Lindström, E.; Larsson, S.H.; Boström, D.; Öhman, M. Slagging Characteristics during Combustion of Woody Biomass Pellets Made from a Range of Different Forestry Assortments. Energy Fuels 2010, 24, 3456-3461. [CrossRef]

97. Öhman, M.; Boman, C.; Hedman, H.; Nordin, A.; Boström, D. Slagging tendencies of wood pellet ash during combustion in residential pellet burners. Biomass Bioenergy 2004, 27, 585-596. [CrossRef]

98. Alyosef, H.A.; Eilert, A.; Welscher, J.; Ibrahim, S.S.; Denecke, R.; Schwieger, W.; Enke, D. Characterization of Biogenic Silica Generated by Thermo Chemical Treatment of Rice Husk. Part. Sci. Technol. 2013, 31, 524-532. [CrossRef] 
99. Santana Costa, J.A.; Paranhos, C.M. Systematic evaluation of amorphous silica production from rice husk ashes. J. Clean. Prod. 2018, 192, 688-697. [CrossRef]

100. Alyosef, H.A. Rice Husk ash (RHA) as a Renewable Source for Value Added Silica: Products the Way to Standardized Educts, Comprehensive Characterization, Modification and Phase Transformation. Ph.D. Thesis, Universität Leipzig, Leipzig, Germany, 2014.

101. Zareihassangheshlaghi, A.; Beidaghy Dizaji, H.; Zeng, T.; Hartmann, I.; Lenz, V.; Enke, D.; Bidabadi, M. Impact of Varying Heating Regimes on Biogenic Silica Obtained from Rice Husk. In Proceedings of the Deutsches Doktorandenkolloquium Bioenergie, Leipzig, Germany, 20-21 September 2018.

102. Gu, S.; Zhou, J.; Luo, Z.; Wang, Q.; Ni, M. A detailed study of the effects of pyrolysis temperature and feedstock particle size on the preparation of nanosilica from rice husk. Ind. Crops Prod. 2013, 50, 540-549. [CrossRef]

103. Rivas, A.L.; Vera, G.; Palacios, V.; Cornejo, M.; Rigail, A.; Solórzano, G. Phase Transformation of Amorphous Rice Husk Silica. In Frontiers in Materials Processing, Applications, Research and Technology; Muruganant, M., Chirazi, A., Raj, B., Eds.; Springer: Singapore, 2018; ISBN 978-981-10-4818-0.

104. Mochidzuki, K.; Sakoda, A.; Suzuki, M.; Izumi, J.; Tomonaga, N. Structural Behavior of Rice Husk Silica in Pressurized Hot-Water Treatment Processes. Ind. Eng. Chem. Res. 2001, 40, 5705-5709. [CrossRef]

105. Bakker, R.R.; Jenkins, B.M.; Williams, R.B. Fluidized Bed Combustion of Leached Rice Straw. Energy Fuels 2002, 16, 356-365. [CrossRef]

106. Knudsen, J.N.; Jensen, P.A.; Dam-Johansen, K. Transformation and Release to the Gas Phase of Cl, K, and S during Combustion of Annual Biomass. Energy Fuels 2004, 18, 1385-1399. [CrossRef]

107. Allendorf, M.D.; Spear, K.E. Thermodynamic Analysis of Silica Refractory Corrosion in Glass-Melting Furnaces. J. Electrochem. Soc. 2001, 148, B59. [CrossRef]

108. Besmann, T.M.; Spear, K.E. Thermochemical Modeling of Oxide Glasses. J. Am. Ceram. Soc. 2002, 85, 2887-2894. [CrossRef]

109. Jenkins, B.M.; Bakker, R.R.; Wei, J.B. On the properties of washed straw. Biomass Bioenergy 1996, 10, 177-200. [CrossRef]

110. Vassilev, S.V.; Baxter, D.; Andersen, L.K.; Vassileva, C.G.; Morgan, T.J. An overview of the organic and inorganic phase composition of biomass. Fuel 2012, 94, 1-33. [CrossRef]

111. Haykiri-Acma, H.; Yaman, S.; Kucukbayrak, S. Effect of biomass on temperatures of sintering and initial deformation of lignite ash. Fuel 2010, 89, 3063-3068. [CrossRef]

112. Jenkins, B.M.; Baxter, L.L.; Miles, T.R. Combustion properties of biomass. Fuel Process. Technol. 1998, 54, 17-46. [CrossRef]

113. Sun, S.; Zhao, Y.; Su, F.; Ling, F. Gasification of rice husk in a cyclone gasifier. Korean J. Chem. Eng. 2009, 26, 528-533. [CrossRef]

114. Madhiyanon, T.; Sathitruangsak, P.; Soponronnarit, S. Co-combustion of rice husk with coal in a cyclonic fluidized-bed combustor ( $\psi$-FBC). Fuel 2009, 88, 132-138. [CrossRef]

115. Williams, P.T.; Nugranad, N. Comparison of products from the pyrolysis and catalytic pyrolysis of rice husks. Energy 2000, 25, 493-513. [CrossRef]

116. Rahman, I.A.; Ismail, J.; Osman, H. Effect of nitric acid digestion on organic materials and silica in rice husk. J. Mater. Chem. 1997, 7, 1505-1509. [CrossRef]

117. Vallios, I.; Tsoutsos, T.; Papadakis, G. Design of biomass district heating systems. Biomass Bioenergy 2009, 33, 659-678. [CrossRef]

118. Hartiniati, S.A.; Youvial, M. (Eds.) Performance of a pilot scale flu-idized bed gasifier fueled by rice husks, pyrolysis and gasifi-cation. International Conference on Pyrolysis and Gasification, Luxembourg City, Luxembourg, 15-18 October 2018.

119. Perera, K.K.C.K.; Rathnasiri, P.G.; Senarath, S.A.S.; Sugathapala, A.G.T.; Bhattacharya, S.C.; Abdul Salam, P. Assessment of sustainable energy potential of non-plantation biomass resources in Sri Lanka. Biomass Bioenergy 2005, 29, 199-213. [CrossRef]

120. Gaur, S.; Reed, T.B. An Atlas of Thermal Data for Biomass and Other Fuels; National Renewable Energy Lab.: Golden, CO, USA, 1995. [CrossRef]

121. Lv, D.; Xu, M.; Liu, X.; Zhan, Z.; Li, Z.; Yao, H. Effect of cellulose, lignin, alkali and alkaline earth metallic species on biomass pyrolysis and gasification. Fuel Process. Technol. 2010, 91, 903-909. [CrossRef] 
122. Singh, R.I.; Mohapatra, S.K.; Gangacharyulu, D. Studies in an atmospheric bubbling fluidized-bed combustor of 10MW power plant based on rice husk. Energy Convers. Manag. 2008, 49, 3086-3103. [CrossRef]

123. Mansaray, K.G.; Ghaly, A.E. Determination of kinetic parameters of rice husks in oxygen using thermogravimetric analysis. Biomass Bioenergy 1999, 17, 19-31. [CrossRef]

124. Sathitruangsak, P.; Madhiyanon, T.; Soponronnarit, S. Rice husk co-firing with coal in a short-combustionchamber fluidized-bed combustor (SFBC). Fuel 2009, 88, 1394-1402. [CrossRef]

125. Channiwala, S.A.; Parikh, P.P. A unified correlation for estimating HHV of solid, liquid and gaseous fuels. Fuel 2002, 81, 1051-1063. [CrossRef]

126. Gungor, A. Two-dimensional biomass combustion modeling of CFB. Fuel 2008, 87, 1453-1468. [CrossRef]

127. Ebeling, J.M.; Jenkins, B.M. Physical and chemical properties of biomass fuels. Trans. Am. Soc. Agric. Eng. 1985, 28. [CrossRef]

128. Buragohain, B.; Mahanta, P.; Moholkar, V.S. Biomass gasification for decentralized power generation: The Indian perspective. Renew. Sustain. Energy Rev. 2010, 14, 73-92. [CrossRef]

129. Zhang, Y.; Ashizawa, M.; Kajitani, S.; Hara, S. A new approach to catalytic coal gasification: The recovery and reuse of calcium using biomass derived crude vinegars. Fuel 2010, 89, 417-422. [CrossRef]

130. Couhert, C.; Commandré, J.-M.; Salvador, S. Failure of the component additivity rule to predict gas yields of biomass in flash pyrolysis at $950{ }^{\circ} \mathrm{C}$. Biomass Bioenergy 2009, 33, 316-326. [CrossRef]

131. Chen, W.-H.; Wu, J.-S. An evaluation on rice husks and pulverized coal blends using a drop tube furnace and a thermogravimetric analyzer for application to a blast furnace. Energy 2009, 34, 1458-1466. [CrossRef]

132. Hossain, M.S.; Islam, M.R.; Rahman, M.S.; Kader, M.A.; Haniu, H. Biofuel from Co-pyrolysis of Solid Tire Waste and Rice Husk. Energy Procedia 2017, 110, 453-458. [CrossRef]

133. Zhang, S.; Dong, Q.; Zhang, L.; Xiong, Y. Effects of water washing and torrefaction on the pyrolysis behavior and kinetics of rice husk through TGA and Py-GC/MS. Bioresour. Technol. 2016, 199, 352-361. [CrossRef]

134. Kumar, A. An approach to the estimation of the value of agricultural residues used as biofuels. Biomass Bioenergy 2002, 22, 195-203. [CrossRef]

135. Sun, L.; Gu, Z.Z.; Guo, D.Y.; Xu, M. Demonstration Systems of Cooking Gas Produced by Crop Straw Gasifier for Villages; Bridgwater, A.V., Boocock, D.G.B., Eds.; Developments in Thermochemical Biomass Conversion; Springer: Dordrecht, The Netherlands, 1997; Volume 1. [CrossRef]

136. Raveendran, K.; Ganesh, A.; Khilar, K.C. Influence of mineral matter on biomass pyrolysis characteristics. Fuel 1995, 74, 1812-1822. [CrossRef]

137. Chao, C.Y.H.; Kwong, P.C.W.; Wang, J.H.; Cheung, C.W.; Kendall, G. Co-firing coal with rice husk and bamboo and the impact on particulate matters and associated polycyclic aromatic hydrocarbon emissions. Bioresour. Technol. 2008, 99, 83-93. [CrossRef] [PubMed]

138. Huang, H.-J.; Yuan, X.-Z.; Zeng, G.-M.; Liu, Y.; Li, H.; Yin, J.; Wang, X.-L. Thermochemical liquefaction of rice husk for bio-oil production with sub- and supercritical ethanol as solvent. J. Anal. Appl. Pyrolysis 2013, 102, 60-67. [CrossRef]

139. Armesto, L.; Bahillo, A.; Veijonen, K.; Cabanillas, A.; Otero, J. Combustion behaviour of rice husk in a bubbling fluidised bed. Biomass Bioenergy 2002, 23, 171-179. [CrossRef]

140. Permchart, W.; Kouprianov, V.I. Emission performance and combustion efficiency of a conical fluidized-bed combustor firing various biomass fuels. Bioresour. Technol. 2004, 92, 83-91. [CrossRef]

141. Sun, S.; Tian, H.; Zhao, Y.; Sun, R.; Zhou, H. Experimental and numerical study of biomass flash pyrolysis in an entrained flow reactor. Bioresour. Technol. 2010, 101, 3678-3684. [CrossRef] [PubMed]

142. Wu, H.-C.; Ku, Y.; Tsai, H.-H.; Kuo, Y.-L.; Tseng, Y.-H. Rice husk as solid fuel for chemical looping combustion in an annular dual-tube moving bed reactor. Chem. Eng. J. 2015, 280, 82-89. [CrossRef]

143. Kwong, C.W.; Chao, C.Y.H. Fly-ash products from biomass co-combustion for VOC control. Bioresour. Technol. 2010, 101, 1075-1081. [CrossRef]

144. Couhert, C.; Commandre, J.-M.; Salvador, S. Is it possible to predict gas yields of any biomass after rapid pyrolysis at high temperature from its composition in cellulose, hemicellulose and lignin? Fuel 2009, 88, 408-417. [CrossRef]

145. Tao, G.; Lestander, T.A.; Geladi, P.; Xiong, S. Biomass properties in association with plant species and assortments I: A synthesis based on literature data of energy properties. Renew. Sustain. Energy Rev. 2012, 16, 3481-3506. [CrossRef] 
146. Wang, X.; Lv, W.; Guo, L.; Zhai, M.; Dong, P.; Qi, G. Energy and exergy analysis of rice husk high-temperature pyrolysis. Int. J. Hydrogen Energy 2016, 41, 21121-21130. [CrossRef]

147. Janvijitsakul, K.; Kuprianov, V.I. Major gaseous and PAH emissions from a fluidized-bed combustor firing rice husk with high combustion efficiency. Fuel Process. Technol. 2008, 89, 777-787. [CrossRef]

148. Zhang, S.; Su, Y.; Zhu, S.; Zhang, H.; Zhang, Q. Effects of pretreatment and FeCl3 preload of rice husk on synthesis of magnetic carbon composites by pyrolysis for supercapacitor application. J. Anal. Appl. Pyrolysis 2018, 135, 22-31. [CrossRef]

149. Zhang, S.; Su, Y.; Ding, K.; Zhu, S.; Zhang, H.; Liu, X.; Xiong, Y. Effect of inorganic species on torrefaction process and product properties of rice husk. Bioresour. Technol. 2018, 265, 450-455. [CrossRef]

150. Zhang, S.; Dong, Q.; Zhang, L.; Xiong, Y.; Liu, X.; Zhu, S. Effects of water washing and torrefaction pretreatments on rice husk pyrolysis by microwave heating. Bioresour. Technol. 2015, 193, 442-448. [CrossRef] [PubMed]

151. Zhang, S.; Dong, Q.; Chen, T.; Xiong, Y. Combination of Light Bio-oil Washing and Torrefaction Pretreatment of Rice Husk: Its Effects on Physicochemical Characteristics and Fast Pyrolysis Behavior. Energy Fuels 2016, 30, 3030-3037. [CrossRef]

152. Zhang, S.; Zhu, S.; Zhang, H.; Chen, T.; Xiong, Y. Catalytic fast pyrolysis of rice husk: Effect of coupling leaching with torrefaction pretreatment. J. Anal. Appl. Pyrolysis 2018, 133, 91-96. [CrossRef]

153. Zhang, S.; Su, Y.; Xu, D.; Zhu, S.; Zhang, H.; Liu, X. Effects of torrefaction and organic-acid leaching pretreatment on the pyrolysis behavior of rice husk. Energy 2018, 149, 804-813. [CrossRef]

154. Zhang, S.; Chen, T.; Xiong, Y.; Dong, Q. Effects of wet torrefaction on the physicochemical properties and pyrolysis product properties of rice husk. Energy Convers. Manag. 2017, 141, 403-409. [CrossRef]

155. Zhang, S.; Su, Y.; Xiong, Y. Influence of coupling demineralization with the torrefaction pretreatment process on the pyrolysis characteristics and kinetics of rice husk. Energy Sour. Part A Recov. Utiliz. Environ. Eff. 2017, 39, 726-732. [CrossRef]

156. Bakker, R.R.; Jenkins, B.M.; Williams, R.B.; Pfaff, D. Fluidized bed combustion of leached rice straw. Proceedings of the 4th biomass conference of the Americas. Available online: https://phyllis.nl/ (accessed on 13 November 2018).

157. Jung, S.-H.; Kang, B.-S.; Kim, J.-S. Production of bio-oil from rice straw and bamboo sawdust under various reaction conditions in a fast pyrolysis plant equipped with a fluidized bed and a char separation system. J. Anal. Appl. Pyrolysis 2008, 82, 240-247. [CrossRef]

158. LU, Y.; GUO, L.; JI, C.; ZHANG, X.; HAO, X.; YAN, Q. Hydrogen production by biomass gasification in supercritical water: A parametric study. Int. J. Hydrogen Energy 2006, 31, 822-831. [CrossRef]

159. Liu, H.; Feng, Y.; Wu, S.; Liu, D. The role of ash particles in the bed agglomeration during the fluidized bed combustion of rice straw. Bioresour. Technol. 2009, 100, 6505-6513. [CrossRef] [PubMed]

160. Miles, T.R.; Baxter, L.L.; Bryers, R.W.; Jenkins, B.M.; Oden, L.L. Boiler deposits from firing biomass fuels. Biomass Bioenergy 1996, 10, 125-138. [CrossRef]

161. Thy, P.; Jenkins, B.M.; Williams, R.B.; Lesher, C.E.; Bakker, R.R. Bed agglomeration in fluidized combustor fueled by wood and rice straw blends. Fuel Process. Technol. 2010, 91, 1464-1485. [CrossRef]

162. Grover, P.D.; Iyer, P.V.R.; Rao, T.R. Biomass-Thermochemical Characterization, 3rd ed.; IIT-Delhi and MNES: Delhi, Indian, 2002.

163. Thy, P.; Jenkins, B.; Grundvig, S.; Shiraki, R.; Lesher, C. High temperature elemental losses and mineralogical changes in common biomass ashes. Fuel 2006, 85, 783-795. [CrossRef]

164. Yang, T.; Wang, J.; Li, B.; Kai, X.; Li, R. Effect of residence time on two-step liquefaction of rice straw in a $\mathrm{CO}_{2}$ atmosphere: Differences between subcritical water and supercritical ethanol. Bioresour. Technol. 2017, 229, 143-151. [CrossRef] [PubMed]

165. Thy, P.; Jenkins, B.M.; Lesher, C.E.; Grundvig, S. Compositional constraints on slag formation and potassium volatilization from rice straw blended wood fuel. Fuel Process. Technol. 2006, 87, 383-408. [CrossRef]

166. Ding, L.; Gong, Y.; Wang, Y.; Wang, F.; Yu, G. Characterisation of the morphological changes and interactions in char, slag and ash during $\mathrm{CO}_{2}$ gasification of rice straw and lignite. Appl. Energy 2017, 195, 713-724. [CrossRef]

167. Wu, Y.; Wu, S.; Li, Y.; Gao, J. Physico-Chemical Characteristics and Mineral Transformation Behavior of Ashes from Crop Straw. Energy Fuels 2009, 23, 5144-5150. [CrossRef] 
168. Chen, C.; Yu, C.; Zhang, H.; Zhai, X.; Luo, Z. Investigation on $\mathrm{K}$ and $\mathrm{Cl}$ release and migration in micro-spatial distribution during rice straw pyrolysis. Fuel 2016, 167, 180-187. [CrossRef]

169. Asadullah, M.; Miyazawa, T.; Ito, S.-I.; Kunimori, K.; Yamada, M.; Tomishige, K. Gasification of different biomasses in a dual-bed gasifier system combined with novel catalysts with high energy efficiency. Appl. Catal. A Gen. 2004, 267, 95-102. [CrossRef]

170. Jenkins, B.M.; Mannapperuma, J.D.; Bakker, R.R. Biomass leachate treatment by reverse osmosis. Fuel Process. Technol. 2003, 81, 223-246. [CrossRef]

171. Li, K.; Zhang, R.; Bi, J. Experimental study on syngas production by co-gasification of coal and biomass in a fluidized bed. Int. J. Hydrogen Energy 2010, 35, 2722-2726. [CrossRef]

172. Chiang, K.-Y.; Liao, C.-K.; Lu, C.-H. The effects of prepared iron-based catalyst on the energy yield in gasification of rice straw. Int. J. Hydrogen Energy 2016, 41, 21747-21754. [CrossRef]

173. Dayton, D.C.; Jenkins, B.M.; Turn, S.Q.; Bakker, R.R.; Williams, R.B.; Belle-Oudry, D.; Hill, L.M. Release of Inorganic Constituents from Leached Biomass during Thermal Conversion. Energy Fuels 1999, 13, 860-870. [CrossRef]

174. Chen, H.; Chen, X.; Qin, Y.; Wei, J.; Liu, H. Effect of torrefaction on the properties of rice straw high temperature pyrolysis char: Pore structure, aromaticity and gasification activity. Bioresour. Technol. 2017, 228, 241-249. [CrossRef] [PubMed]

175. Dong, Q.; Zhang, S.; Ding, K.; Zhu, S.; Zhang, H.; Liu, X. Pyrolysis behavior of raw/torrefied rice straw after different demineralization processes. Biomass Bioenergy 2018, 119, 229-236. [CrossRef]

176. Miccio, F.; Moersch, O.; Spliethoff, H.; Hein, K.R.G. Generation and conversion of carbonaceous fine particles during bubbling fluidised bed gasification of a biomass fuel. Fuel 1999, 78, 1473-1481. [CrossRef]

177. Storm, C.; Spliethoff, H.; Hein, K.R.G. Generation of a gaseous fuel by gasification or pyrolysis of biomass for use as reburn gas in coal-fired boilers. In Proceedings of the 5th European Conference on Industrial Furnaces and Boilers, Porto, Portugal, 11-14 April 2000; Volume 1.

178. WEI, X.; SCHNELL, U.; HEIN, K. Behaviour of gaseous chlorine and alkali metals during biomass thermal utilisation. Fuel 2005, 84, 841-848. [CrossRef]

179. Fernandes, I.J.; Calheiro, D.; Kieling, A.G.; Moraes, C.A.M.; Rocha, T.L.A.C.; Brehm, F.A.; Modolo, R.C.E. Characterization of rice husk ash produced using different biomass combustion techniques for energy. Fuel 2016, 165, 351-359. [CrossRef]

180. Souza, M.F.d.; Magalhães, W.L.E.; Persegil, M.C. Silica Derived from Burned Rice Hulls. Mater. Res. 2002, 5, 467-474. [CrossRef]

181. Yalçin, N.; Sevinç, V. Studies on silica obtained from rice husk. Ceram. Int. 2001, 27, 219-224. [CrossRef]

182. Vassilev, S.V.; Baxter, D.; Vassileva, C.G. An overview of the behaviour of biomass during combustion: Part I. Phase-mineral transformations of organic and inorganic matter. Fuel 2013, 112, 391-449. [CrossRef]

183. Vassilev, S.V.; Baxter, D.; Andersen, L.K.; Vassileva, C.G. An overview of the chemical composition of biomass. Fuel 2010, 89, 913-933. [CrossRef]

184. Vassilev, S.V.; Baxter, D.; Vassileva, C.G. An overview of the behaviour of biomass during combustion: Part II. Ash fusion and ash formation mechanisms of biomass types. Fuel 2014, 117, 152-183. [CrossRef]

185. Pollex, A.; Zeng, T.; Khalsa, J.H.A.; Erler, U.; Schmersahl, R.; Schön, C.; Kuptz, D.; Lenz, V.; Nelles, M. Data Set of Potassium and Other Aerosol Forming Elements in High Quality Wood Pellets, 2017. [CrossRef]

186. Alvarez, J.; Lopez, G.; Amutio, M.; Bilbao, J.; Olazar, M. Bio-oil production from rice husk fast pyrolysis in a conical spouted bed reactor. Fuel 2014, 128, 162-169. [CrossRef]

187. Umeda, J.; Kondoh, K. High-purification of amorphous silica originated from rice husks by combination of polysaccharide hydrolysis and metallic impurities removal. Ind. Crops Prod. 2010, 32, 539-544. [CrossRef]

188. Krishnarao, R.V.; Subrahmanyam, J.; Jagadish Kumar, T. Studies on the formation of black particles in rice husk silica ash. J. Eur. Ceram. Soc. 2001, 21, 99-104. [CrossRef]

189. Shen, J.; Liu, X.; Zhu, S.; Zhang, H.; Tan, J. Effects of calcination parameters on the silica phase of original and leached rice husk ash. Mater. Lett. 2011, 65, 1179-1183. [CrossRef]

190. Chen, G.; Du, G.; Ma, W.; Yan, B.; Wang, Z.; Gao, W. Production of amorphous rice husk ash in a $500 \mathrm{~kW}$ fluidized bed combustor. Fuel 2015, 144, 214-221. [CrossRef]

191. Liou, T.-H. Preparation and characterization of nano-structured silica from rice husk. Mater. Sci. Eng. A 2004, 364, 313-323. [CrossRef] 
192. Liou, T.-H. Evolution of chemistry and morphology during the carbonization and combustion of rice husk. Carbon 2004, 42, 785-794. [CrossRef]

193. Lu, P.; Hsieh, Y.-L. Highly pure amorphous silica nano-disks from rice straw. Powder Technol. 2012, 225, 149-155. [CrossRef]

194. Ahmad Alyosef, H.; Schneider, D.; Wassersleben, S.; Roggendorf, H.; Weiß, M.; Eilert, A.; Denecke, R.; Hartmann, I.; Enke, D. Meso/Macroporous Silica from Miscanthus, Cereal Remnant Pellets, and Wheat Straw. ACS Sustain. Chem. Eng. 2015, 3, 2012-2021. [CrossRef]

195. Gu, S.; Zhou, J.; Yu, C.; Luo, Z.; Wang, Q.; Shi, Z. A novel two-staged thermal synthesis method of generating nanosilica from rice husk via pre-pyrolysis combined with calcination. Ind. Crops Prod. 2015, 65, 1-6. [CrossRef]

196. Liaw, S.B.; Wu, H. Leaching Characteristics of Organic and Inorganic Matter from Biomass by Water: Differences between Batch and Semi-continuous Operations. Ind. Eng. Chem. Res. 2013, 52, 4280-4289. [CrossRef]

197. Werkelin, J.; Skrifvars, B.-J.; Zevenhoven, M.; Holmbom, B.; Hupa, M. Chemical forms of ash-forming elements in woody biomass fuels. Fuel 2010, 89, 481-493. [CrossRef]

198. Said, N.; Bishara, T.; García-Maraver, A.; Zamorano, M. Effect of water washing on the thermal behavior of rice straw. Waste Manag. 2013, 33, 2250-2256. [CrossRef] [PubMed]

199. Bakar, R.A.; Yahya, R.; Gan, S.N. Production of High Purity Amorphous Silica from Rice Husk. Procedia Chem. 2016, 19, 189-195. [CrossRef]

200. Umeda, J.; Kondoh, K.; Michiura, Y. Process Parameters Optimization in Preparing High-Purity Amorphous Silica Originated from Rice Husks. Mater. Trans. 2007, 48, 3095-3100. [CrossRef]

201. Chakraverty, A.; Mishra, P.; Banerjee, H.D. Investigation of combustion of raw and acid-leached rice husk for production of pure amorphous white silica. J. Mater. Sci. 1988, 23, 21-24. [CrossRef]

202. Schliermann, T.; Hartmann, I.; Schneider, D.; Wassersleben, S.; Enke, D.; Jobst, T.; Lange, A.; Roelofs, F.; Fellner, A.; Schneider, P. High-quality biogenic silica from agricultural residues. In Tagungsband Waste-to-Resources, Proceedings of the 7th International Symposium MBT, MRF E Recycling, Hannover, Germany, 16-18 May 2017; Cuvillier Verlag: Göttingen, Germany, 2017; pp. 676-687.

(C) 2019 by the authors. Licensee MDPI, Basel, Switzerland. This article is an open access article distributed under the terms and conditions of the Creative Commons Attribution (CC BY) license (http:/ / creativecommons.org/licenses/by/4.0/). 